\title{
EARLY RIFT SEDIMENTATION AND STRUCTURE ALONG THE NE MARGIN OF BAJA CALIFORNIA
}

\author{
Joann M. Stock ${ }^{1}$, Arturo Martín-Barajas ${ }^{2}$, and Miguel Tellez-Duarte ${ }^{3}$ \\ ${ }^{1}$ Caltech 252-21, Pasadena CA 91125 USA \\ ${ }^{2}$ Ciencias de la Tierra, CICESE, Ensenada BC Mexico \\ ${ }^{3}$ Facultad de Ciencias Marinas, UABC, Ensenada BC Mexico
}

\section{INTRODUCTION}

This field trip will examine deposits and structures in four basins of NE Baja California which formed during Neogene rifting in the Gulf of California Extensional Province (Fig. 1). Our objective is to provide an overview of depositional environments and facies, and tectonic controls on the basin evolution, as a guide to interpreting early rift basins elsewhere around the Gulf of California as well as at other incipient oceanic rifts. The basins we will visit range in age from middle Miocene (the continental deposits of the Santa Rosa basin) to late Miocene (upper part of the Santa Rosa basin, and the San Felipe marine sequence) to Pliocene (San Felipe marine sequence, Puertecitos Formation, and Laguna Salada sequence). They include both marine and nonmarine deposits, and record variations in sedimentation rate and tectonic patterns that are regionally important in the thermal and structural evolution of the northern Gulf of California. They also lie in different structural settings within the rift system.

\section{EXTENSION IN THE GULF EXTENSIONAL PROVINCE OF NE BAJA CALIFORNIA}

This excursion will visit sites within the Gulf Extensional Province of northeastern Baja California. In this region, the extensional province is bounded on the west by the Main Gulf Escarpment, on the east by the Gulf of California, on the north by faults of the San Andreas system, and on the south by the Puertecitos Volcanic Province.

The Main Gulf Escarpment (Gastil and others, 1975 ) is a generally east-facing topographic slope, coincident with the steep eastern sides of the Sierra de Juárez and Sierra San Pedro Mártir. This escarpment reaches a topographic relief of $2.5 \mathrm{~km}$ west of San Felipe, east of the $3000 \mathrm{~m}$ elevation crest of the Sierra San Pedro Mártir. At this latitude, the escarpment is controlled by a major E-dipping normal fault, the San Pedro Mártir fault. However, along the Laguna Salada segment, there is a discontinuous series of N-NW striking, west- and east-dipping normal faults (Romero-Espejel, 1996). Elsewhere, at the junction between separate, fault-controlled steep

in Patrick L. Abbott and John D. Cooper., eds., 1996,

Field Conference Guide 1996. Pacific Section A.A.P.G, GB 73,

Pacific Section S.E.P.M, Book 80, p.337-372. segments of the escarpment, the escarpment topography can be quite subtle (Lee and others, 1996). This variation of structural styles and fault dips along the Main Gulf Escarpment has led to the concept of separate structural segments separated by accommodation zones (Axen, 1995), as discussed further below.

From the international border south to the Puertecitos Volcanic Province, the Gulf Extensional Province contains basin and range topography and range-bounding normal faults, with some NWstriking dextral and ENE-striking sinistral strike-slip faults. However, at the latitude of the Puertecitos Volcanic Province, the topography and faulting style change dramatically. The modern structural grain of the Puertecitos Volcanic Province is dominated by closely spaced $\mathrm{N}$ - to NW-striking normal faults, both synthetic and antithetic to the faults of the Main Gulf Escarpment located approximately $30 \mathrm{~km}$ to the west (Dokka and Merriam, 1982). In a broad sense, structures at the latitude of the Puertecitos Volcanic Province may be transferring slip out towards the Gulf of California along an accommodation zone (Dokka and Merriam, 1982; Stock and Hodges, 1990; Axen, 1995). Other accommodation zones within the Gulf Extensional Province may be related to changes in dip direction of the escarpment fault systems (Axen, 1995).

The Puertecitos accommodation zone is a point of dramatic structural change in character and style of extension within the extensional province. From the southern end of the San Pedro Mártir fault to Puertecitos, within the Gulf Extensional Province, the $\sim 6$ Ma rocks are severely deformed (Lewis, 1994; Stock, unpublished mapping). The $\sim 6 \mathrm{Ma}$ deformation, the younger rifting and development of marine basins, and the modern structural pattern may all be expressions of a structural zone linking extension at the western edge of the Gulf Extensional Province and slip along the San Pedro Mártir fault, to the transform/spreading system of the Gulf of California.

The fault pattern in the eastern PVP suggests ENE-directed extension and deformation of the Pliocene volcanic and sedimentary rocks (MartínBarajas and Stock, 1993). Local angular and erosional unconformities, fault-controlled 
Figure 1. Regional geologic map of the northern Gulf Extensional Province in Baja California.

Segments and accommodation zones after Stock and Hodges (1990) and Axen (1995). Geologic background simplified from INEGI 1:250 000 geologic maps.

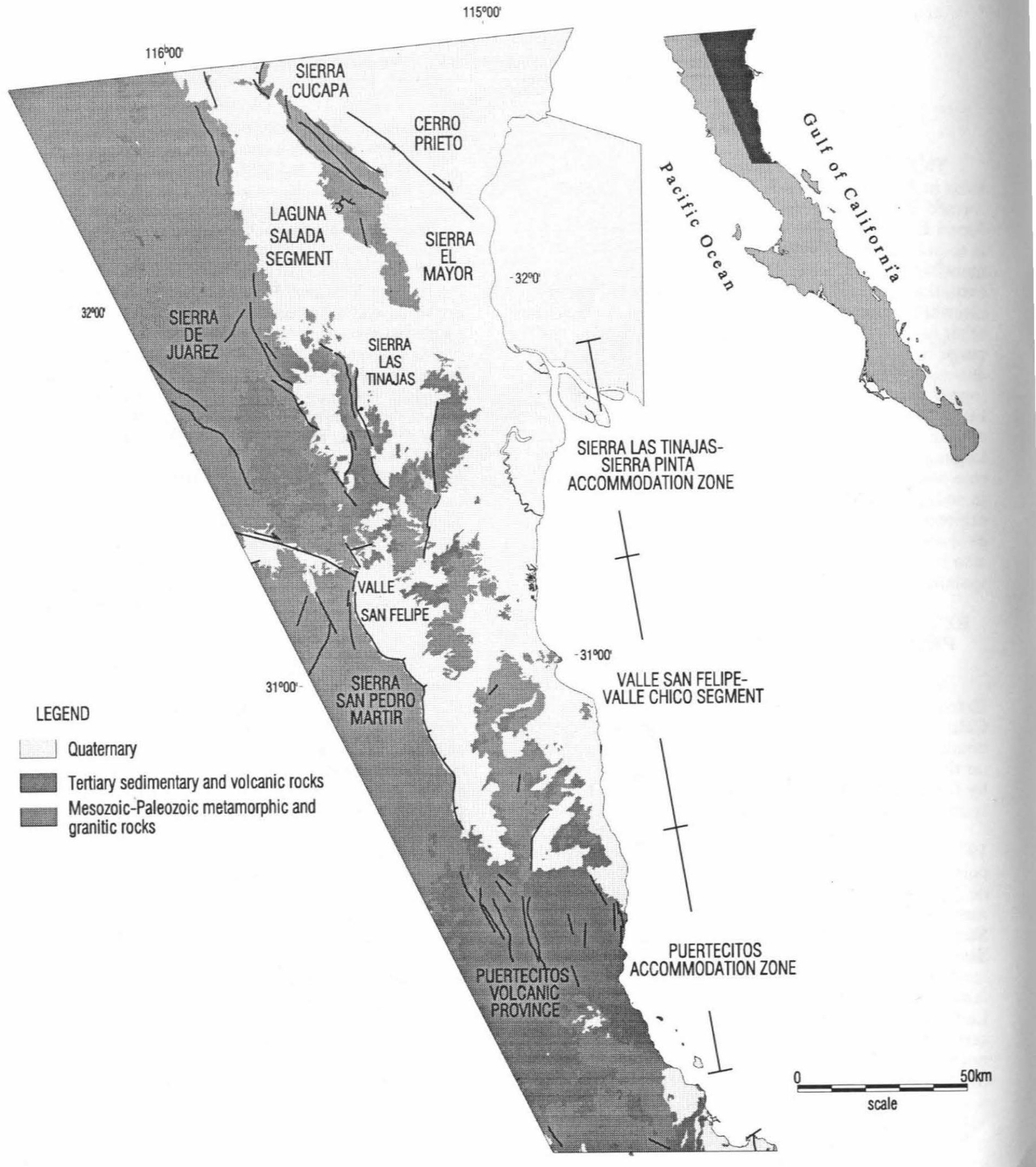


paleotopography and facies distribution indicate that normal faulting and tilting occurred during and after deposition of the Pliocene units.

East-northeast-striking left-lateral strike-slip faults are also present in the Sierra San Fermín and the northernmost part of the Sierra Santa Isabel (south of Arroyo Matomí). These faults cut the Pliocene sedimentary and volcanic rocks. Fault traces visible on aerial photos cut Quaternary alluvium across Arroyo Matomí; they are also reported in the coastal zone east of the Sierra San Fermín (Lewis, 1994; Rebolledo-Vieyra, 1994). The NEstriking, sinistral strike-slip faults may represent boundaries of clockwise rotated blocks as demonstrated by paleomagnetic studies (Lewis and Stock, submitted to JGR, 1995; Rebolledo-Vieyra, 1994). Faults of this strike are also common on existing maps of the Sierra San Felipe (Gastil and others, 1975) and Santa Rosa basin (Bryant, 1986), suggesting that this more recent fault pattern might, in fact, represent the modern deformational style throughout much of the Gulf Extensional Province in northeastern Baja California.

\section{MEXICALI VALLEY}

Stratigraphically, the western side of the Mexicali Valley consists of an east-directed wedge of alluvial fan deposits from the Sierra Cucapá (Puente and de la Peña, 1979). A thick and continuous sandstone ribbon is reported to occur further east at $\sim 800 \mathrm{~m}$ depth, separating the alluvial fan deposits from Sierra Cucapa and the deltaic facies of the ancient Colorado River. This sand body is important because it may represent coastal-deltaic deposits and the marine seaway that connected the Salton Trough and the northern Gulf in Pliocene time (Lyons and van de Kamp, 1979). In the western Imperial Valley, California, intermittent shallow marine deposition continued until middle Pleistocene time, and Lyons and van Kamp (1979) interpret this sandy facies as the connection to the Gulf west of the Colorado delta up to that time.

A second path for sea water to the Salton Trough may have existed along the Laguna Salada basin. At least two localities in the eastern margin of Laguna Salada (Yuha desert and Sierra El Mayor) contain Pliocene marine and deltaic deposits likely correlated with the Imperial and Palm Spring Fms (Siem, 1992; Isaac, 1987). An exploratory well by the Comision Federal de Electricidad (CFE) indicates up to $2300 \mathrm{~m}$ of pre-Imperial deposits (mostly Palm Spring Formation) on the eastern margin (Alvarez and González-López, 1995). This suggests that sporadic flooding of the Colorado River delta occurred from Late Pliocene to Pleistocene time through Laguna Salada. Subsequently, a southward shift of the delta and the activity along the Laguna Salada - Elsinore fault system may have uplifted and closed the river and marine connections between the Salton Trough, the Laguna Salada basin, and the Gulf.

\section{SIERRA CUCAPA, SIERRA MAYOR, AND LAGUNA SALADA FAULT}

The Sierra Cucapá contains Paleozoic-Mesozoic rocks and Jurassic (?) and Cretaceous intrusive bodies, in various tectonic slices separated by major oblique-dextral and normal fault zones (Barnard, 1968; Gastil and others, 1975; Mueller and Rockwell, 1991). The western rangefront of the Sierra Cucapa is controlled by the Laguna Salada fault (LSF), an active northwest-striking obliquedextral slip fault (Fig. 2). The LSF is responsible for the late Quaternary uplift of the range and the development of the elongated Laguna Salada Basin (Barnard, 1968; Mueller and Rockwell, 1991). Uplift of the Sierra Cucapá also resulted from interaction of a number of subparallel major fault

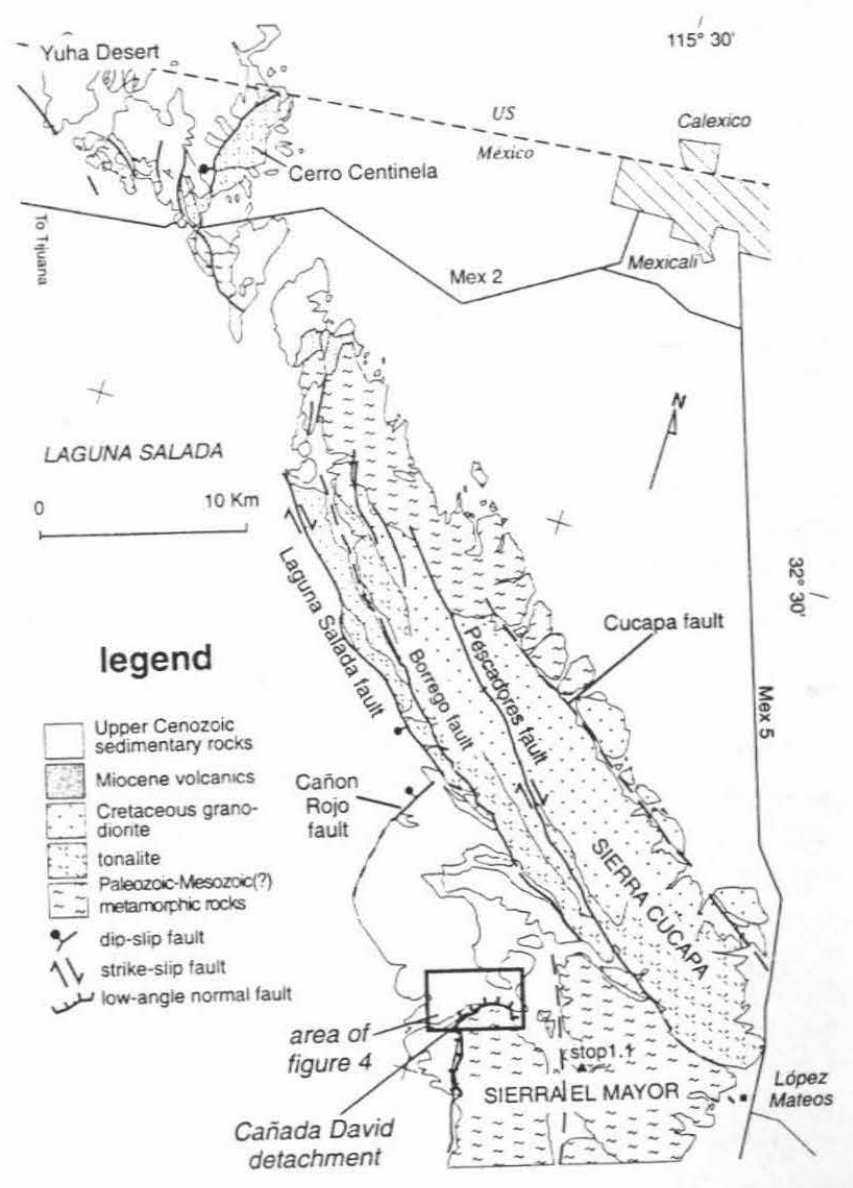

Figure 2. Geologic map of the Sierra Cucapa and northern Sierra El Mayor (adapted from Barnard, 1968). 
zones with dextral and oblique slip, including the Cerro Prieto, Cucapá, Pescadores, and Borrego faults (Figs 1 and 2).

The southern Sierra Cucapá and the northern Sierra Mayor include extensive outcrops of marble and quartzo-feldspathic gneisses, but sillimanitealmandine gneisses and biotite-rich schistose gneisses are widespread (Barnard, 1968; Siem, 1992). The age of the sedimentary protolith is unknown, except that it is older than an intrusive (La Puerta tonalite) with an apparent age of 125-155 $\mathrm{Ma}$ (U-Pb, zircon) (Barnard, 1968). On the basis of the rarity of quartzite and moderate abundance of carbonate beds, the age of the metasedimentary rocks of the Sierra Cucapa is proposed to be within the range of Permian to Jurassic (Barnard, 1968). Farther south, Paleozoic rocks have been described in the Sierra Pinta by Leier-Engelhardt (1993).

The La Puerta tonalite is well exposed in the southeastern part of the Sierra Cucapa, and also occurs in an elongate northwest-trending body in the western half of the range (Fig. 2). The rock is highly variable in composition and texture. It is strongly foliated, medium to coarse grained, hornblende-biotite tonalite (quartz diorite) with sphene as a common accessory (Barnard, 1968). In some places, the tonalite resembles metasedimentary gneisses, and the contact with metasedimentary rocks is concordant and gradational in the central part of the range, whereas, most of the southwest margin of this intrusive is fault-bounded (Barnard, 1968). The central part of the Sierra Cucapa is a granodiorite pluton which intrudes the metasedimentary rocks and the La Puerta tonalite (Barnard, 1968). This rock is distinctive because of its light color, which contrasts with the darker color of the metamorphic and tonalitic rocks previously described. The contact with the metasedimentary rocks is very sharp, but concordant to foliation and bedding.

\section{LAGUNA SALADA BASIN}

The Laguna Salada basin is a prominent morphological feature $\sim 20 \mathrm{~km}$ in width extending $\sim 100 \mathrm{~km}$ in a NNW direction into the southwestern Imperial Valley. The basin is bounded on the west by the Sierra Juárez, and on the east by the Sierra Cucapá and Sierra El Mayor. Gravimetric studies indicated that the sedimentary fill of the Laguna Salada basin might be 5-6 km thick (Kelm, 1971; Chávez, 1990). However, a new isostatic residual gravity map (García-Abdeselem and others, 1996) suggests a ramp-like basement deepening eastwards, with a maximum sedimentary thickness of $\sim 3.5 \mathrm{~km}$ on the eastern side of the basin. No major structural disruptions occur across the central and western parts of the basin.
The area east of Laguna Salada, in the northern Sierra Mayor, contains late Miocene to early Pliocene marine strata correlated with the Imperial Formation, and nonmarine fanglomerates and deltaic deposits correlated with the Palm Spring Formation (Barnard, 1968; Siem, 1992). Recent work on the stratigraphy and sedimentary environments, based on new lithologic and paleontologic data, has resulted in better definition of the stratigraphic limits among the Imperial and Palm Spring formations and overlying conglomerates in this area (Vázquez-Hernández, 1996; Vázquez-Hernández and others, this volume). In addition, this area is important because the sedimentary rocks lie in the upper plate of an exhumed low-angle normal fault system, the uppermost structure of which is the Cañada David detachment fault (CDDF) (Fig. 2). The CDDF juxtaposes these upper Tertiary deposits against lower-plate crystalline basement rocks (Paleozoic (?) metasedimentary rocks and Mesozoic to Tertiary(?) igneous basement rocks.

Recent geologic mapping indicates that the topographic escarpment of the Sierra Juárez contains a discontinuous series of N-NW striking, west- and east-dipping normal faults (RomeroEspejel, 1996). The lack of a single major fault controlling the Sierra Juárez escarpment, and the presence of the westward-directed low angle normal fault system in the Laguna Salada Basin, suggests that this low-angle normal fault system may have controlled the basin subsidence in its early stage. Since Pleistocene time, the oblique-slip Laguna Salada fault played a major role in the localization of the depocenter, as mentioned above.

\section{Stratigraphy and General Facies Description}

The stratigraphy of the upper plate of the CDDF includes up to $1 \mathrm{~km}$ of marine, deltaic and alluvial fan deposits. The composite stratigraphic sections of both Siem (1992) and VázquezHernández (1996) are shown in Fig. 3.

\section{Imperial Formation}

The Imperial Formation in Laguna Salada comprises 3 informal members (Fig. 3). A lower conglomerate and breccia unit (Tim1 on Fig. 3) overlies the basement rocks along a fault contact (Vázquez-Hernández et al, this volume). Tim1 is equivalent to Units 1 and 2 of Siem (1992), which are unconformably overlain by the mudstone facies Tim2 (Unit 3 of Siem, 1992).

This conglomerate and breccia unit varies both laterally along strike and vertically up section. In the western Sierra El Mayor, Tim1 consists of alternating layers of matrix-supported conglomerate and breccia, and medium- to coarse-grained lithic sand 
Figure 3. General stratigraphic logs of the late Neogene sedimentary sequence in the eastern Laguna Salada basin. a) adapted from Siem (1992). b) adapted from Vázquez-Hérnandez and others, this vol. The thickness corresponds to the maximum continuous outcrop of individual units. Tim1, Imperial Formation lower (?) member; Tim2, Imperial mudstone member; Tim3, Imperial sandstone member; Ps, Palm Spring sandstone and siltstone; Pac, Cañon Rojo sandy conglomeratic facies; Pc, Cañon Rojo conglomerate facies.

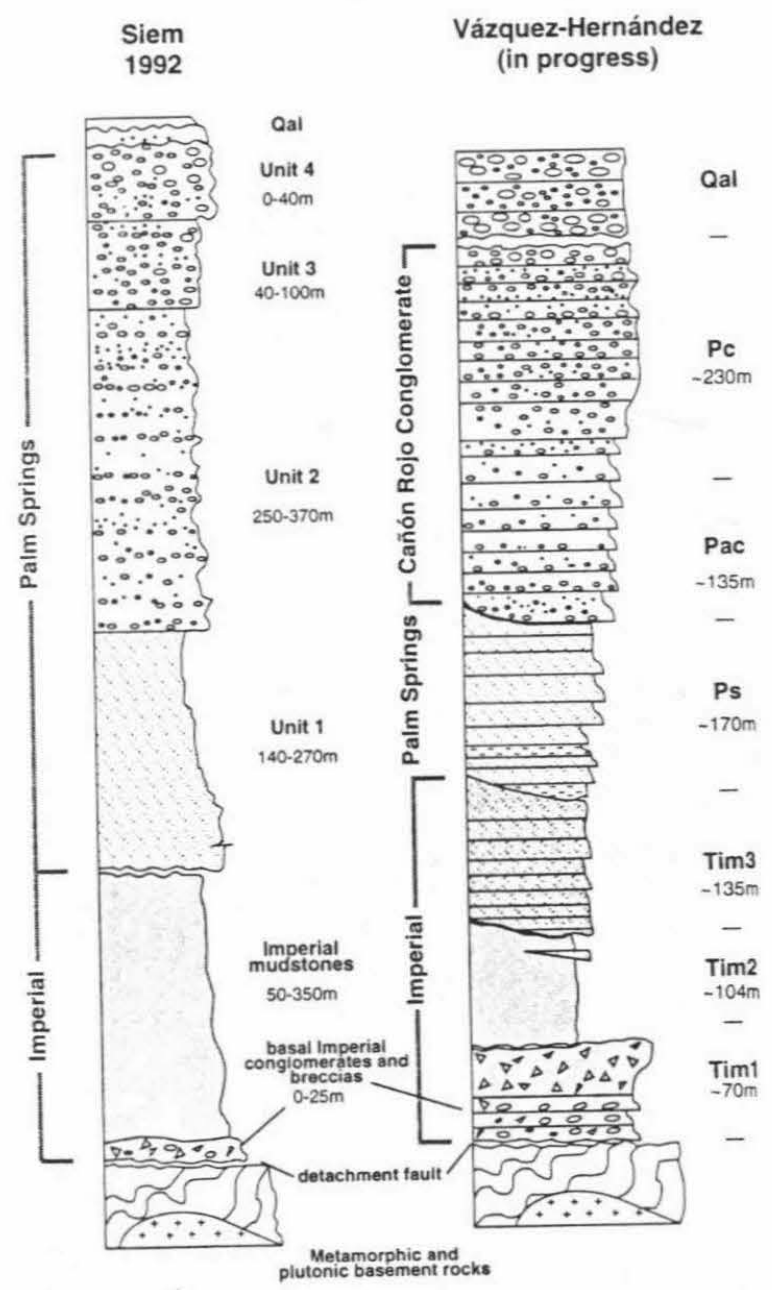

beds (Siem, 1992). This deposit lacks bioclasts and calcareous matrix, and was considered a separate unit by Siem (1992).

The outcrop at Nightstalker Ridge (stop 3A on Fig. 4) shows Tim1 in fault contact with the underlying basement shear zone. The sedimentary breccia varies in character both along strike and vertically. Here, the outcrop is a chaotic, poorly sorted, clast-supported breccia. The clasts are angular and consist of locally derived metamorphic and granitic basement rocks. This subfacies grades upsection into a relatively well sorted lithic sandstone, and then into a sequence of sandstone-mudstone couplets.

The outcrop at Coral Hill (Fig. 4) consists of poorly sorted, matrix-supported breccia, with no paleoflow indicators. Pebble to cobble clasts are well rounded and the larger cobbles and boulders are angular to subangular. The presence of bioclasts (oyster shell, corals, and boring ichnofossils) has been reported by Siem (1992) as a distinctive feature. However, subsequent work by VázquezHernández and Martín-Barajas failed to find bioclasts or microfossils. Fossils reported from this unit include oysters, pectinids, marble clasts with borings, and corals (Siem, 1992).

The section described by Vázquez-Hernández includes up to $70 \mathrm{~m}$ of medium to thickly bedded matrix-supported conglomerate grading upwards into clast-supported conglomeratic breccia. The sequence dips up to $40^{\circ}$ towards the north. These beds are interpreted as proximal deposits of a fandelta, including sheet deposits and gravity flow deposits, probably associated with synsedimentary faulting.

The reported fauna is indicative of near shore, shallow water, high energy marine environments, similar to the environments reported for the Latrania Member of the Imperial Formation in the Imperial Valley, California (Siem, 1992). But in the Sierra El Mayor, the fossils in the conglomerate and breccia are definitely reworked. The top of the unit is faulted, but is inferred to underlie the mudstone facies (Unit 3 of Siem, 1992; and unit Tim2 of Vázquez Hernández, 1996).

A transition to fine grained sandstone deposits is clearly exposed at stop $3 \mathrm{~A}$, but the contact with the distinct yellow mudstone is faulted. The stratigraphic sections yield $\sim 100 \mathrm{~m}$ as a maximum continuous thickness in the mudstone facies (Tim2) (Vázquez-Hernández, 1996). Upwards, the mudstone facies grades to muddy sandstone and then into rhythmically bedded sandstone, with coquina lenses and beds. The sandstone facies crops out in the western part of the area and is considered to be a different member by Vázquez-Hernández (1996) (Tim3 in Fig. 3).

Tim 2 is chiefly composed of yellow-green, silty to sandy mudstone, with a few sandstone lenses and. beds of fine grained sandstone, gypsum and coquina (Siem, 1992; Vázquez-Hernández, 1996). The mudstone is massive and poorly laminated, with penetrative anastomosing cleavage surfaces, and fibrous gypsum filling the fractures. This facies dominates the eastern exposures of the Imperial Fm 


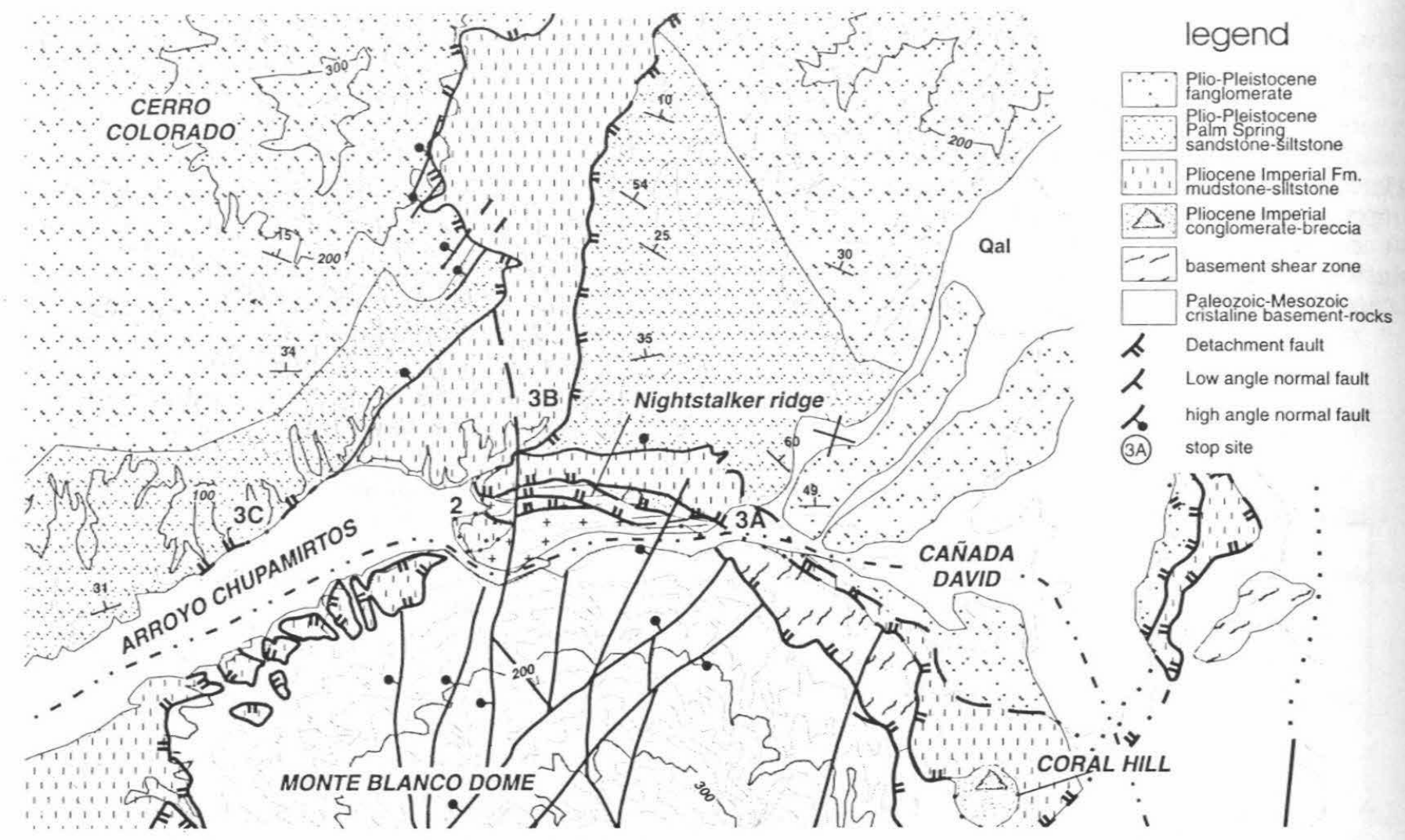

Figure 4. Geologic map of the Cañada David - Arroyo Chupamirto area (adapted from Siem, 1992). The geologic contact between Ps and Pac-Pc is from Vázquez-Hernández (1996).

north of the Sierra El Mayor. To the west, Tim3 includes up to $170 \mathrm{~m}$ of fine to medium grained sandstone with numerous coquina lenses and beds. It is separated from the mudstone facies on the basis of the coarser sediments, the sedimentary structures and the microfossil assemblage which indicate shallower intertidal conditions (Vázquez-Hernández and others, this volume).

This facies has been tectonically removed by low-angle normal faults on the eastern flank of Cerro Colorado (Fig. 4). This means that the Imperial Fm. varies from external platform or talud (Tim2) to intertidal (Tim3), with the overall geometry suggesting a coarsening upward sequence. The shift to shallower water conditions may have resulted from a combination of tectonic uplift and higher sediment input from the Colorado River.

\section{Palm Spring Formation}

The Palm Spring Formation generally overlies the Imperial Formation either in fault contact, or in angular unconformity. A gradational contact also occurs north of Cerro Peñasco (see Fig. 1 of Vázquez-Hernández et al, this volume). The Palm Spring Formation, as defined by Dibblee (1954), marks the transition from marine to deltaic environments in the Salton Trough. In Laguna Salada, the Palm Spring Fm includes up to $170 \mathrm{~m}$ of muddy sandstone to gravelly sandstone beds. Upwards the transition to a reddish coarse-grained sandstone and the dominance of conglomerate beds marks the change to alluvial fan deposits, which have been mapped as a separate unit (Vázquez-Hernández, 1996). These coarse deposits are labeled the Cañon Rojo conglomerate (Pac and Pc in Fig. 3). Siem (1992) includes the same conglomerate sequence in the upper part of the Palm Spring Formation, but recent geologic mapping indicates that these deposits are distal to proximal facies across alluvial fans formed during an early episode of activity of the Laguna Salada fault. Locally, the reddish conglomerate deposits lie in angular unconformity over the Palm Spring Formation. In other places this contact is conformable and it is marked by an abrupt color change from brown-beige to red (Vázquez-Hernández, 1996). In the southern rangefront of Sierra Cucapá, the old fanglomerate deposits, mostly conglomerate and breccia, crop out extensively, due to exhumation by the activity of the Laguna Salada fault. These deposits consist of alternating matrix-supported to clast-supported 
conglomerate beds that laterally pass into matrixsupported to clast-supported breccia with blocks several meters long, and are equivalent to the sandy conglomerate unit that crops out in Cerro Colorado (Pac). At Cañon Rojo, this conglomerate and breccia are mainly composed of hornblende tonalite clasts, and have an arkosic matrix, with hematitic cement. The sequence dips generally to the east, and is disrupted by numerous NNW-striking normal and oblique-slip sinistral faults. This fault array is likely related to the activity of the Laguna Salada fault system in Pleistocene time.

\section{Microfossil and Paleoenvironments of the Imperial Formation in Laguna Salada.}

The microfossil determinations and the lithologic characteristics of the Imperial Formation here indicate shallower water depths up-section. The mudstone-claystone facies (Tim2) contains a microfossil assemblage corresponding to upper bathyal to outer platform (Vázquez-Hernández and others, this volume). By contrast, the sandy facies (Tim3) has a foraminiferal assemblage indicating shallow marine to brackish water conditions. The deep water mudstone facies also contains reworked foraminifera from the platform (Vázquez-

Hernandez and others, this volume).

Unfortunately, none of the autochthonous species identified allow reliable age constraints. Throughout the Imperial Formation the nannoplankton show fragmentation and dissolution. Consequently, they were not useful for age determination. Nevertheless, the assemblage includes abundant Cretaceous species. Cretaceous microfossils (foraminifera) have also been reported in well cuttings from the Cerro Prieto Geothermal field, and in the southwestern Imperial Valley, in Coyote Mountain Clays (Cotton and Vonder Haar, 1979; Quinn and Cronin, 1984). These microfossils are interpreted to have been carried by the ancestral Colorado River (Bell-Countryman, 1984); the source rock may be the Upper Cretaceous Mancos shale of the Colorado Plateau (Merriam and Bandy, 1965; Lucchitta, 1972). These data are relevant because they suggest that the mudstone facies (facies 3 of Siem, 1992 and Tim2 of VázquezHernández, 1996) of the Imperial Formation from Laguna Salada correlates with the Coyote Mountain Clays in the southwestern Imperial Valley. Deeper water conditions may, however, have existed for the mudstone facies in Laguna Salada, as suggested by the microfossil assemblage (Vázquez-Hernández and others, this vol.).

No marine microfossils are reported to occur in the Palm Spring Formation. Reworked oyster and clam shells are occasionally found in the sandstone facies of the Palm Spring Formation. Our preliminary observations indicated that palynomorphs and dinofla-gellates are relatively abundant. These microfossils are being identified by J. Helenes at CICESE, and hopefully this will provide age constraints for the stratigraphic section.

\section{Structural Controls on Facies}

The two dominant Neogene structures of this region are the Sierra El Mayor core complex (Siem and Gastil, 1994) and the Laguna Salada fault (Mueller and Rockwell, 1991). The Laguna Salada fault is an active, oblique right-lateral strike-slip fault, striking NNW (Figs. 1 and 2). This fault provides the modern structural control on the Laguna Salada basin. The Sierra El Mayor core complex is associated with a now inactive, northdipping, low-angle detachment fault system, including a basement shear zone and the Cañada David detachment fault (CDDF). This separates the Miocene and Pliocene sedimentary sequence from underlying Mesozoic basement rocks (plutonic and metamorphic) and has produced a spectacular turtleback-like surface on the northern slope of the Sierra Mayor.

All exposures of the Imperial Formation in this region have a basal fault contact with the underlying metamorphic and plutonic rocks. Nowhere is the base of the depositional sequence exposed. In addition, other low-angle normal faults are found higher in the section, within the sequence of basin sediments.

The low-angle normal fault system (including the Cañada David detachment fault), and related structures in this region, were described by Siem and Gastil (1994) (Fig. 4). The CDDF zone consists of a black cataclastic to ultracataclastic zone ( 0.5 to $1 \mathrm{~m}$ thick). An underlying basement shear zone is warped into a smoothly antiformal surface over the Monte Blanco Dome. This basement shear zone consists of a set of stacked horizontal shear zones involving variably deformed basement rocks, often displaced by higher-angle small-offset normal faults forming sets of asymmetric boudins and/or drag folds.

Tertiary cataclastic fabrics including boudin orientations and S-C fabrics, and striae on higherangle faults, indicate that movement along this fault system was top-to-the-west (Siem and Gastil, 1994). The basement shear zone appears to have been truncated by younger slip along the CDDF, contemporaneous with deposition of the Imperial Formation in this region. Siem and Gastil (1994) interpret the deposition of the Palm Spring Formation to be after the principal slip on the CDDF but to have been accompanied by continued low-angle normal faulting higher in the section, within the Palm Spring and Imperial formations. 
High-angle normal faults affecting the Palm Spring Formation, but not the overlying Quaternary gravels, indicate a change to a NW direction of extension before Quaternary time.

\section{SAN FELIPE MARINE SEQUENCE}

Our subsequent field trip stops will examine basin deposits from San Felipe to Puertecitos (Fig. 5). Marine deposits crop out in the Cuevitas Pass region, WNW of San Felipe, on both sides of the present topographic pass (e.g., Gastil and others, 1975; Andersen, 1973). These grade up into shallow water and nonmarine deposits. These deposits are important for the constraints they provide on paleodepths and paleoenvironments within the Gulf of California during late Miocene and Pliocene time. In particular, the lowest unit, the San Felipe diatomite member, indicates middle bathyal depths in this part of the Gulf at 5.5 - 6.0 Ma.

We will examine these rocks east of Cuevitas Pass (Fig. 6). The biostratigraphy and lithostratigraphy of the outcrops here, a composite section $340 \mathrm{~m}$ thick, were extensively studied by Boehm (1982; 1984).

\section{Overall Stratigraphy}

The depositional sequence indicates generally shallowing upward conditions in two marine units separated by an unconformity (Fig. 6): the Miocene-Pliocene Llano el Moreno Formation, and the Pliocene Salada Formation. These are overlain by various Pliocene and/or Quaternary alluvial fan deposits. The Llano el Moreno Formation is further subdivided into the older San Felipe Diatomite Member and the younger Cañon Las Cuevitas Mudstone Member. The base of the sequence is not exposed.

The lowest unit, the San Felipe Diatomite Member, indicates middle bathyal depths in this part of the Gulf at $5.5-6.0 \mathrm{Ma}$ (Table 1). This unit is composed of laminated to very lightly bioturbated, thin bedded, slightly tuffaceous diatomite. Upsection, as content of volcanic material increases, there is a gradational contact with the overlying Cañon Las Cuevitas Mudstone Member. This Member is characterized by tuffaceous, lightly bioturbated, silty mudstones and sandy siltstones.

The Salada Formation is characterized by continued sandstone and siltstone beds, and abundant macrofossils. It includes shallow marine sands, distal alluvial fan sands, and occasional sandy pebble to cobble conglomerate. It represents regression and shallower water to nonmarine conditions, along with a change in provenance from the volcanic source (of the Cañon Las Cuevitas Mudstone Member) to a local source of batholithic composition.

\section{General Facies Descriptions}

Boehm (1982) divided the San Felipe Marine Sequence into four major lithofacies with several subfacies, which correspond to the lithostratigraphic units. A general lithofacies description follows.

Llano El Moreno Formation, San Felipe Diatomite Member (30m):

\section{Lithofacies A.}

This corresponds to the lower member of the Llano El Moreno Formation. The sediments are composed of fine grained siliceous biogenic debris, mostly diatoms, along with minor quantities of

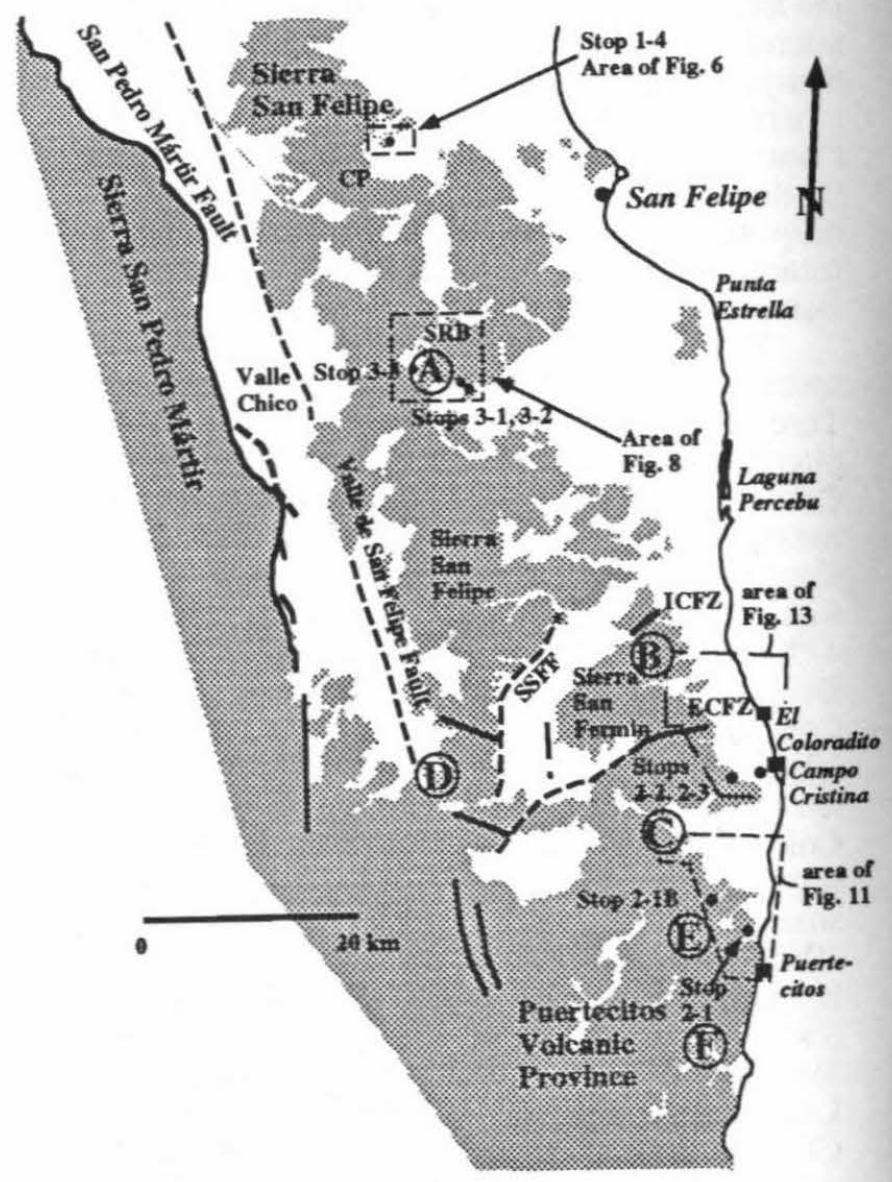

Figure 5. Map of the coastal zone between San Felipe and Puertecitos, showing the location of field trip stops and detail maps. $\mathrm{CP}=$ Cuevitas Pass. ECVZ $=\mathrm{El}$ Coloradito fault zone. ICFZ = Ironwood Canyon fault zone. SRB = Santa Rosa Basin. SSFF = Sierra San Felipe fault. Letters in circles (A-F) indicate locations of volcanic sections shown in Fig. 16. 


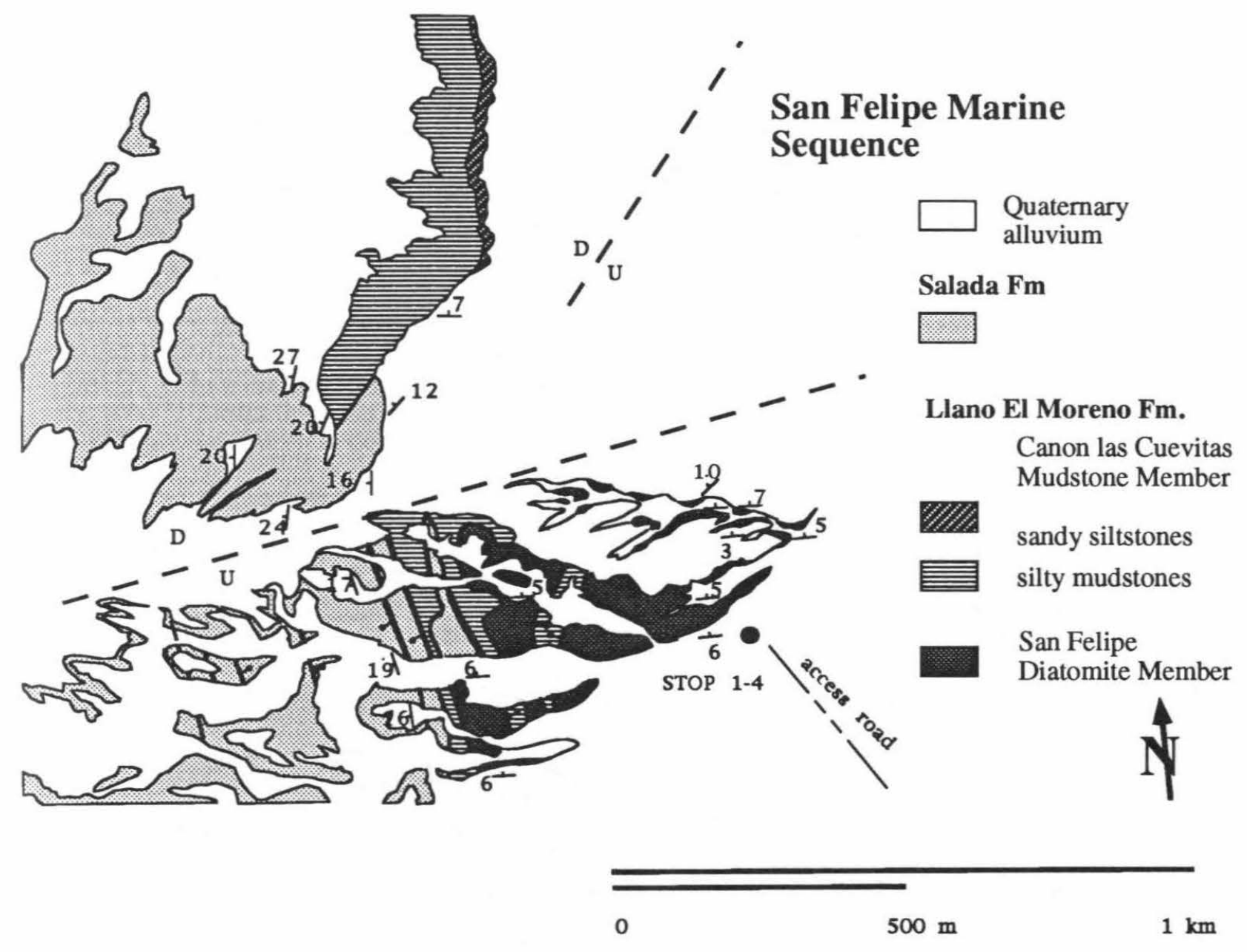

Figure 6. Detail map of San Felipe marine sequence outcrops, showing exposures near stop 1-4 (after Boehm, 1982).

colloidal silica, smectite and illite, and fresh pumice clasts. Three distinctive subfacies can be recognized: A1) non-laminated diatomite, although it is sometimes fissile; A2) laminated diatomite, similar to the previous subfacies, but with laminations between 2.0 and $5.0 \mathrm{~mm}$ thick; and A3) thinly bedded clays, which occur rarely, commonly interbedded with laminated diatomite along sharp upper and lower contacts. The clay composition is almost entirely smectite, with subsidiary quantities of biotite. Diagenetic alteration to porcelanite commonly is found at the upper and lower contacts with the diatomite.

Evidence indicates that lithofacies A was deposited at an upper middle bathyal depth. There are several possible scenarios for the sedimentary process. The first could be long-term pelagic and hemipelagic sedimentation, or continuous settling of biologically packaged material as fecal pellets. Both subfacies A1 and A2 make up the bulk of lithofacies $A$, indicating high productivity surface waters isolated from terrigenous sedimentation. The laminated diatomite is associated with low dissolved oxygen conditions, which exclude benthic bioturbation (Calvert, 1964, Ingle, 1981). Alternation of laminated and non-laminated cycles suggests fluctuations in the oxygen minimum due to eustatic, climatic and circulation patterns. In some cases it may be due to low-angle sediment slumping.

The sedimentation here may also be controlled by periodic decreases in the surface water productivity, with increased volcanism creating sediment gravity flows (subfacies A3 clays), as indicated by the scarcity of microfossils and the abundance of smectite, averaging $80 \%$, derived from the diagenetic alteration of volcanic products. 
Table 1. Main events related to deposition of the stratigraphic units of the San Felipe Marine Sequence.

\begin{tabular}{|c|c|c|c|}
\hline Time M.a. & Stratigraphic Unit & Depth & Main events \\
\hline$<3.0$ & Salada Formation & Subaerial exposure & $\begin{array}{l}\text { Subaerial emergence } \\
\text { and erosion. Folding } \\
\text { and faulting related } \\
\text { with the Gulf rifting }\end{array}$ \\
\hline 3.0 & & Shelf-coastal & $\begin{array}{l}\text { Rapid uplifting, } \\
\text { increased sediment } \\
\text { size. Initiation of } \\
\text { Gulf of California } \\
\text { transtensional rifting }\end{array}$ \\
\hline 5.0 & $\begin{array}{l}\text { Cañón Las Cuevitas } \\
\text { Mudstone }\end{array}$ & $\begin{array}{l}\text { Uppermost middle } \\
\text { bathyal }\end{array}$ & $\begin{array}{l}\text { Global climatic } \\
\text { deterioration } \\
\text { disminishes primary } \\
\text { productivity and } \\
\text { increases hemipelagic } \\
\text { sedimentation }\end{array}$ \\
\hline$>6.0$ & San Felipe Diatomite & Middle bathyal & $\begin{array}{l}\text { Dysaerobic } \\
\text { conditions with some } \\
\text { aerobic, volcanic, and } \\
\text { gravity flows events }\end{array}$ \\
\hline
\end{tabular}

Llano El Moreno Formation, Cañón Las Cuevitas Member $(65 \mathrm{~m})$

\section{Lithofacies B.}

The base of Lithofacies B is in gradational contact with the top of the San Felipe Diatomite Member. The transition occurs in less than $2.5 \mathrm{~m}$. Boehm (1982) recognized two subfacies here:

Subfacies B1 (Mudrocks). These are generally medium to thick bedded $(10-100 \mathrm{~cm})$, but thickness varies greatly. They are internally bioturbated, fine grained sediments, with sand-sized material making up less than $10 \%$ of the total rock. Compositionally, this facies is dominated by alkali feldspars with lesser amounts of biotite, plagioclase, foraminifera and quartz. Smectite makes up about $80 \%$ of the clays, illite $15-20 \%$, and minor amounts of kaolinite and chlorite are also present. Secondary dolomite occurs very locally, as thin beds, concretionary zones, pervasive cements, or scattered crystals and detrital grains. This suggests, similar to what is seen in the San Felipe Diatomite Member, shallow burial depth, low sediment temperatures, and the association of carbon dioxide and methane.

Texturally and mineralogically, this facies is similar to the San Felipe Diatomite member, except for the lack of siliceous biogenic debris. Hemipelagic deposition is indicated by the preservation of laminations (lack of bioturbation). Some distal turbidites may be present, as is suggested by rare increase in grain size of the silt and sand fractions along with transported foraminifera and graded bedding.

Subfacies B2 (Muddy Sands). This facies has roughly equal amounts of sand and sub-sand-sized material loosely packed, very friable and almost unlithified, without microfossils. Again, alkali feldspars are dominant, but quartz and volcanic lithics make up about $10 \%$ of the total. Bedding is difficult to discern, but several pumiceous horizons define irregular bedding surfaces. Macrofossils are scarce and consist of unidentified pectinid fragments, the only ones in the Llano El Moreno Formation. This subfacies probably represents gravity flow deposits, liquefied or grain flow. 
Salada Formation:

\section{Lithofacies C:}

Most of the Salada Formation is composed of arkosic sands, with coarser horizons thinning out eastward. This represents a change in provenance from the fine-grained hemipelagic volcanic source during deposition of the Cañon Las Cuevitas Member, to a sand-yielding, tonalitic and granodioritic batholithic source of the Sierra de San Felipe and Sierra de Santa Rosa. This change in provenance may be due to the uplift of the Gulf coastal ranges, related to the initiation of transtensional Gulf rift ing. The sand was deposited in shallow marine enviroments, ranging from beachface to inner shelf.

Lithofacies C lies in angular unconformity on the upper part of Cañon Las Cuevitas Mudstone Member. Scarce reworked microfossils from the Llano El Moreno Formation are present within 10 meters of the contact. Macrofossils are locally abundant in a thin layer $105 \mathrm{~m}$ above the basal unconformity; however, bioturbation is very common within the Salada Formation, except in the upper $140 \mathrm{~m}$.

Lithofacies C is divided by Boehm (1982) into a number of subfacies. The main subfacies have the following distinctive characteristics and internal structures: C1, small scale trough cross-bedded lithic arkosic, calcite-cemented sands. Microfossils are rare and fragmented; C2) Planar cross-bedded sands, lacking cementation; C3) Bioturbated planar bedded fine arkosic sands, and horizons with abundant megafossils; C4) Coarse clastic-bearing sands, with some fragmented bivalves; C5) Large scale cross-bedded sands, occurring very locally in incised scours, and C6) orthoconglomerates composed of granitic and granodioritic clasts. Subfacies $\mathrm{C} 1$ and $\mathrm{C} 2$ are indicative of a beachface environment, C3 of sublittoral offshore, C4 alluvial fan, and C5 and C6 fan channel.

\section{Fossil Assemblage and Age of Deposits}

Micropaleontological analysis, including foraminifera, diatoms, silicoflagellates, radiolarian and coccolithophorids and rare megafossils in portions of the SFMS indicates that these sediments were deposited during late Miocene (5.5 to $6.0 \mathrm{Ma}$ ) through Pleistocene time (Boehm, 1984).

\section{San Felipe Diatomite Member}

Age-diagnostic microfossils at the base of San Felipe Diatomite Member are the diatom Thalassiosira convexa var. aspinosa and the radiolarian Didymocyrtus (Omatartus) antepenultimus, whose biostratigraphic ranges constrain the date to 5.5-6.0
Ma. Concurrent last and first appearance of the radiolaria Spongaster pentas and Didymorcistis penultimus constrain the date of the uppermost sequence to 3.6 Ma (Theyer and others, 1978).

\section{Cañon Las Cuevitas Mudstone Member}

The scarcity of planktic foraminifera and virtual absence of siliceous microfossils makes it difficult to assign a precise date to this unit. However, the Salada Formation invertebrate megafauna suggest that the top of the Mudstone Member must be older than $1.8 \mathrm{Ma}$, and for that Boehm (1982) assigns a conservative late Pliocene age of $3.4 \mathrm{Ma}$, taking into account the extensive regional faulting and uplift in NE Baja California.

Salada Formation

A few age-diagnostic megafossils, which include Encope tenuis Kew and Ostrea heermanni Conrad from coquina beds, indicate a Pliocene age for the Salada Formation (Hertlein, 1968; Andersen, 1973). Ten of 26 species described by Hertlein (1968) are correlative with the Imperial Formation, which is assumed to be no younger than $1.8 \mathrm{Ma}$ and not older than $3.4 \mathrm{Ma}$.

\section{Evolution of Facies}

The SFMS lithologic and paleontologic trends show a rapid shoaling during Pliocene time. Micropaleontologic evidence from the San Felipe Diatomite Member, along with lithofacies, suggest a water depth of at least $400 \mathrm{~m}$ for lithofacies A. Two key species, Buliminella subfusiformis and Virgulina punctata, and the abundance of planktic foramini-fera, diatoms and radiolaria are associated with upper bathyal benthic biofacies. On the other hand, maximum depth is indicated by the abundant radio-laria, which are common at depths in excess of $1000 \mathrm{~m}$ (Heckel, 1972). These biofacies must be related to low oxygen fluctuations rather than just than the bathymetry, due to the rare presence of Uvigerina species, which are abundant in subfacies B.

Progressive basin shoaling is suggested by the gradational change to lithofacies B of the Cañon Las Cuevitas Member. The abundance of Uvigerina species is related to more oxygenated waters (Douglas, 1981), as is the evidence of burrowing organisms such as the ichnofossils Arenicolites and Chondrites.

Deposition of lithofacies $\mathrm{C}$ represents the most abrupt change during the basin evolution. As a consequence of the Gulf of California rifting, the basal Salada Formation lithofacies C experienced rapid uplift from upper middle bathyal depths to 
shallow coastal conditions. After that, only one slight deepening occurred, followed by non-marine alluvial-fluvial sedimentation which continued into Pleistocene time (Boehm, 1984).

\section{Structural Controls on Deposition}

Although there is a gradational contact between the Diatomite Member and Mudstone Member, dip directions in the area are quite variable, without a consistent pattern, except on fault related slump blocks. The Mudstone Member appears to overlie an undulatory depositional surface, not unreasonable for a slope environment (Boehm, 1982).

Prior to deposition of the Salada Formation, the area underwent north-south compression forming a series of low amplitude east-west trending folds, which Boehm (1982) tentatively related to the first transtensional motion in the northern Gulf related to the San Andreas transform system. The uplift and eastward tilting of the Llano El Moreno Formation in late Pliocene time raised the basin from upper middle bathyal depths to littoral depths and caused the unconformable contact with the Salada Formation. Subsequent faulting displaced the contact, which is visible only in the southernmost region of the area (Fig. 6). During Pleistocene time the region was differentially tilted westward and northward, causing the angular unconformity at the base of the Quaternary alluvium.

The major faults in the area are NE-striking and $\mathrm{N}$-striking normal faults which disrupt the Salada Formation and underlying units. The Nstriking faults have down-to-the-west normal separation, and are offset by ENE-striking faults with $\mathrm{N}$-side-down and sinistral separation. They may be antithetic to a fault along the rangefront of the Sierra San Felipe here. A set of NNW-striking normal faults, with dips to both $\mathrm{E}$ and $\mathrm{W}$, appear locally and may accommodate differential slip along the ENE-striking faults.

\section{Correlations with Adjacent Areas}

Boehm (1982) recognized abundant tuffaceous material in this section. It is not clear that any of the material is primary; however, high concentrations of rounded pumice lapilli, up to $2 \mathrm{~cm}$ in diameter, in lenses within the upper part of the Llano el Moreno Formation and the Salada Formation suggest a minimal amount of reworking. These pumice lapilli are similar in composition to some of the tuffaceous horizons of the marine Puertecitos Formation, exposed farther south along the coast.

\section{SANTA ROSA BASIN}

The Santa Rosa basin lies within the Sierra San Felipe, about $20 \mathrm{~km}$ southwest of the city of San Felipe (Fig. 5). It contains nonmarine sedimentary rocks, tuffs, and local basalt flows, ranging in age from pre-15 Ma to Pliocene. Stratigraphically, this basin is significant because it contains evidence of a major change in sediment provenance believed to be coincident with the development of relief along the Main Gulf Escarpment to the west (Gastil and others, 1975). It also represents the only wellstudied example of major middle to late Miocene, predominantly alluvial and lacustrine sedimentation, in this part of the Gulf of California. Structurally, this basin is important for three reasons: (1) the basin is bounded by a SE-dipping low-angle normal fault which was active in Pliocene time; (2) the basal strata of the basin include outcrops of a pre-15 Ma conglomerate that provides a tie point across the Gulf of California to the Sonoran side; (3) the basin exhibits clear evidence of multiple stages of faulting which can be related to the stages of evolution of the Gulf of California. The following discussion is based on work of Bryant (1986) and our subsequent structural and sampling reconnaissance. Stratigraphy of the basin was described by Bryant (1986) and is summarized in Fig. 7. The basin deposits are now tilted northwest and west, around a gentle NW-trending fold axis (Fig. 8). Because the region is cut by many small drainages, the section is generally very well exposed. The thickness of the basin deposits is estimated to be at least $2.5 \mathrm{~km}$. Three widely exposed tuffs in the lower part of the basin provide useful marker horizons in the sedimentary succession. The section is divided into three sequences on the basis of depositional and tectonic environments. These sequences overlie granitic to dioritic batholithic rocks and local prebatholithic metasedimentary rocks. Detailed facies analysis has not been done, but in general, the sedimentary rocks include both locally derived units (eolian deposits, proximal alluvial fan, or monolithologic breccias) and units more distant from their sources (mudstones, distal fan deposits, welded tuffs, and fluvial conglomerates).

Sequence 1 consists of basal sedimentary rocks (unit Tos), starting with calcite-cemented arkosic sandstone. Frosted quartz grains near the base locally suggest an eolian origin. Overlying the sandstone are local pockets of braided stream gravels, including a conglomerate with subrounded to rounded cobbles of a variety of compositions. This conglomerate is notable for two reasons: (1) occasional limestone clasts in the conglomerate contain Permian fusilinids and crinoid fragments from a probable source in Sonora (Gastil and others, 1973); (2) imbrications of the cobbles suggest a current direction from the northeast (Bryant, 1986). This conglomerate may be late Oligocene or 
Miocene in age; the only age constraint from the Santa Rosa Basin is that 15 Ma basalt overlies Tos. A similar basal unit of sandstones grading up into cobble conglomerates is known from the Sierra San Fermín, $30 \mathrm{~km}$ to the SSE. These are also interpreted as braided stream deposits with westward paleocurrent directions; they are interbedded with $21 \mathrm{Ma}$ basalts and thus are at least partly Early Miocene in age (Lewis, 1996).

Sequence 2 dominates the basin section in the Santa Rosa Basin. This package of immature sediments and volcanic units was considered by Bryant (1986) to be internally conformable. The lowermost volcanic units in Sequence 2 are local olivine basalts which yielded a $\mathrm{K}$-Ar whole rock age of $15.0 \pm 0.4 \mathrm{Ma}$ (Gastil and others, 1979); a welded tuff, $\mathrm{Tmr}_{1}$; and local lamprobolite andesite.

Characteristics of $\mathrm{Tmr}_{1}$ are described below (see "Age range and regional correlations of units").

Above $\mathrm{Tmr}_{1}$, most of Sequence 2 is made up of sedimentary rocks, which Bryant (1986) divided into three packages: $\mathrm{Tmf}_{1}, \mathrm{Tmf}_{2}$, and $\mathrm{Tmf}_{3}$. These, and the volcanic units which separate them, are described individually below.

Tmf1 is a sequence of alluvial fan deposits with abundant immature, poorly sorted, coarse-grained sediments. Conglomerates are dominantly matrixsupported, with angular to subrounded clasts of local provenance (basement plutonic rocks and welded tuff). Sandstone beds are medium to coarse-grained, arkosic wackes, with moderately sorted, subangular grains (dominantly feldspar and volcanic lithics) and approximately $15 \%$ interstitial clay. Some mudstones are found interbedded with the sandstones, particularly in the southern part of the basin. The map unit $\mathrm{Tmf}_{1}$, as defined by Bryant (1986), shows a fining-upwards trend in the northern part of the basin but a coarsening-upwards trend in the central and southern parts of the basin.

Above $\mathrm{Tmf}_{1}$ lies the middle major tuff, Tmt. This nonwelded rhyolitic tuff forms a white marker bed with a maximum thickness of $16 \mathrm{~m}$ in the central region of the basin, decreasing towards the north and south. Bryant (1986) reports phenocrysts of sanidine, quartz, hornblende, and biotite, as well as volcanic lithic fragments. The resistant upper surface of the Tmt outcrops often form distinctive hogbacks.

Above Tmt, a fining-upward sequence of alluvial fan units $\left(\mathrm{Tmf}_{2}\right)$ was deposited. These range from clast-supported conglomerates and matrixsupported debris flows to mudstones with prominent dessication cracks. The dominant lithologies are arkosic wacke and pebble conglomerate. Bryant (1986) reported clast imbrications indicating current directions toward the NNE and a generally southwestern source. The estimated maximum thickness of this unit is $140 \mathrm{~m}$ in the central part of the basin.

The $\mathrm{Tmf}_{2}$ units are overlain by volcanic units, first, locally, an amygdaloidal olivine basalt which was dated at $8.9 \pm 1.2 \mathrm{Ma}$ by $\mathrm{K}-\mathrm{Ar}$ on plagioclase (Valdez, 1977), and then a welded tuff with spherulitic zones. The welded tuff, $\mathrm{Tmr}_{2}$, is more regionally extensive. It yielded ages of $12.3 \pm 1.8 \mathrm{Ma}$ (K/Ar whole rock) and $13.6 \pm 2.4 \mathrm{Ma}(\mathrm{K} / \mathrm{Ar}$ whole rock on the basal vitrophyre) (Bryant, 1986). The ages of the basalt and the tuff are out of sequence, and each must be treated with caution.

Overlying these volcanic units is the thickest part of the basin section - the alluvial deposits of

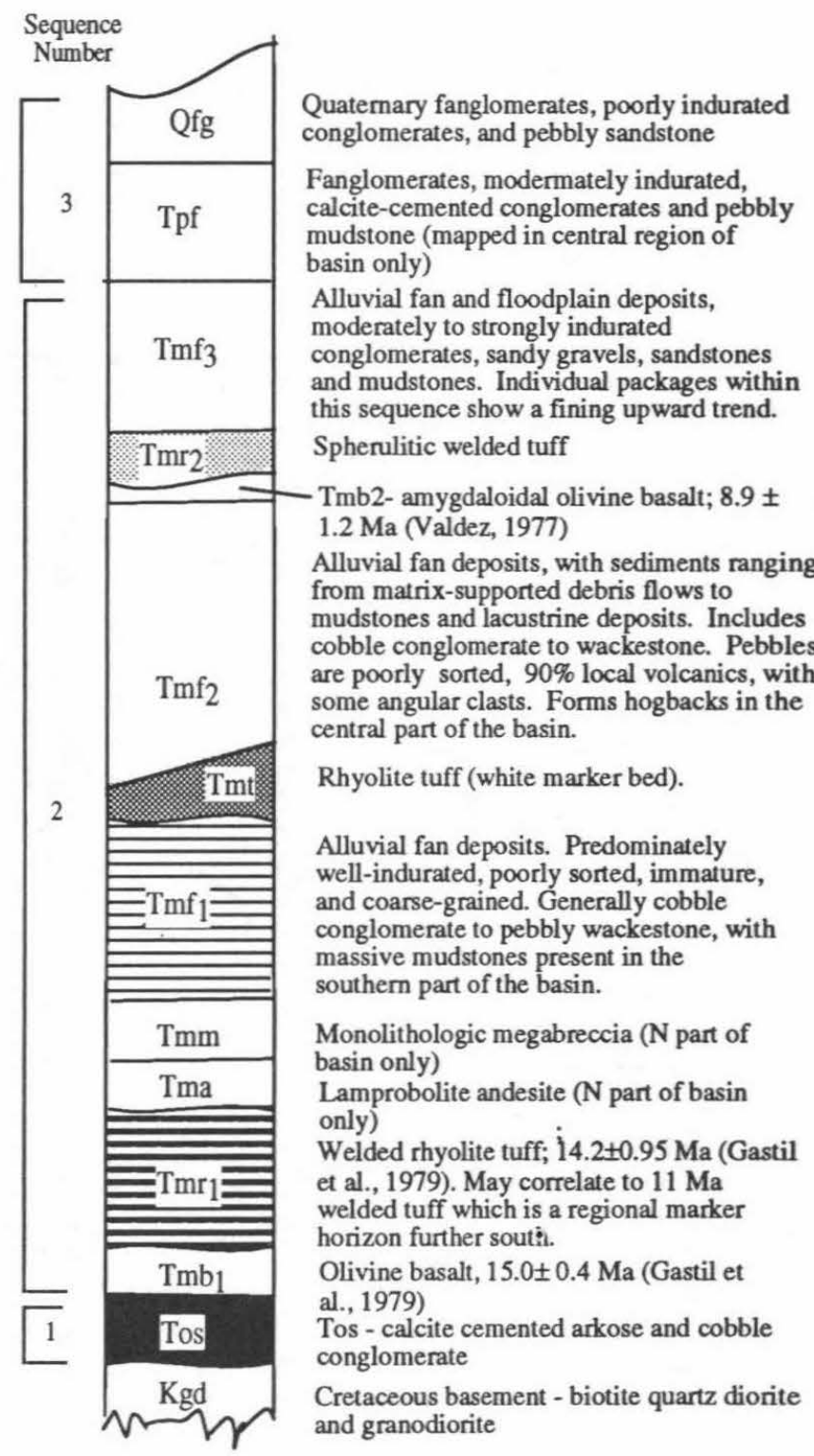

Figure 7. Summary stratigraphic section of the Santa Rosa Basin (after Bryant, 1986). 


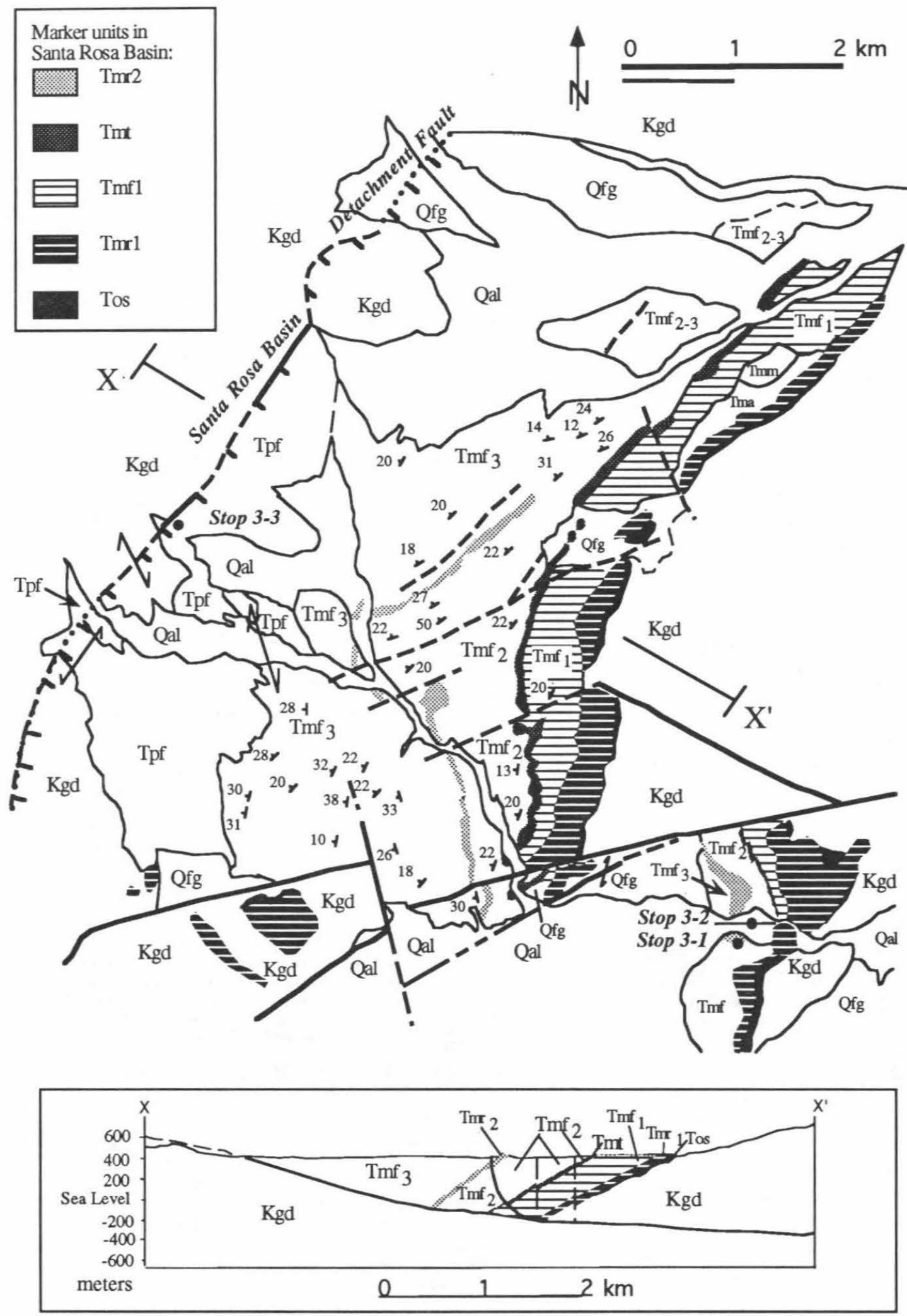

Figure 8. Map and cross section of the Santa Rosa Basin, after Bryant (1986). See Fig. 7 for complete stratigraphic column. See Fig. 5 for location of map. Patterns are the same as in Fig. 7. 
$\mathrm{Tmf}_{3}$, estimated to be at least $0.5 \mathrm{~km}$ thick. These contain interbedded mudstones and sandstones, defining several individual fining-upwards packages. Depositional environments are inferred to range from mid-fan to distal fan and flood plain. Ripple marks in the lower third of the unit suggest $\mathrm{N}$-S current directions. Clast imbrications, together with the predominance of basement clasts, suggest a W or NW source region for the upper part of the sequence (Bryant, 1986).

Sequence 3 consists of younger alluvial deposits of local origin, which are separated from Sequence 2 by a well-defined unconformity. The sediments of Sequence 3 include a unit of younger fanglomerates (Tpf) along the western side of the basin. The clasts are from local source areas (basement lithologies and volcanic rocks). Tpf is poorly sorted and moderately indurated, with a maximum thickness of $30 \mathrm{~m}$ where it is now being dissected in arroyos. Overlying, poorly indurated conglomerates which are less dissected are inferred to be Quaternary in age (unit Qal of Bryant, 1986).

\section{Age Range and Regional Correlations of Units}

Bryant (1986) considered all of the volcanic units present in the Santa Rosa Basin to be local deposits, without correlative units outside the basin. However, at the time of his study, detailed work had not been done to the south or west of this area. Subsequent work in these regions suggests that the oldest tuff, which he labeled $\mathrm{Tmr}_{1}$, may be regionally present. This is a densely welded, devitrified, crystalrich tuff. It had been dated at $14.2 \pm 0.9 \mathrm{Ma}$ by KAr whole rock (Gastil and others, 1979). In the Santa Rosa basin, this tuff contains sanidine, quartz, plagioclase, biotite, and hornblende. It reaches a thickness of $60 \mathrm{~m}$ at the SE corner of the Santa Rosa Basin.

We think that this unit may correlate with a regionally extensive welded tuff, $11 \mathrm{Ma}$ in age, whose vent area was about $30 \mathrm{~km}$ to the south, at the northern end of the Sierra San Fermín. The latter unit was also labeled Tmr1 by Stock $(1989,1993)$ and Lewis (1996); where studied by them, the mineralogy includes anorthoclase, plagioclase, orthopyroxene, clinopyroxene, basaltic hornblende, and minor quartz. This unit reaches a thickness of $80 \mathrm{~m}$ in the Parral Canyon area of the Sierra San Fermín, and it has yielded ${ }^{40} \mathrm{Ar}-{ }^{39} \mathrm{Ar}$ ages of $11.0 \pm 0.6 \mathrm{Ma}$ (Lewis, 1995). It is present on both sides of southern Valle Chico (40 km S of the Santa Rosa Basin), where its maximum thickness is $30 \mathrm{~m}$. An ${ }^{40} \mathrm{Ar}-{ }^{39} \mathrm{Ar}$ total fusion age of $10.85 \pm 0.32 \mathrm{Ma}$ was obtained on anorthoclase crystals from a sample collected along the Main Gulf Escarpment, 50 km SW of the Santa Rosa Basin (Stock, 1989). Further
${ }^{40} \mathrm{Ar} /{ }^{39} \mathrm{Ar}$ work on feldspars from $\mathrm{Tmr}_{1}$ in the Santa Rosa Basin is in progress to check this correlation. The lowermost volcanic unit, olivine basalt, is similar in age to other olivine basalts in adjacent areas such as Valle Chico and the Sierra San Fermín (Stock, 1989; Lewis, 1996).

Bryant (1986) suggested that map unit Tpf in the Santa Rosa Basin might correlate with fanglomerates mapped by Andersen (1973) further north, where they intertongue with marine rocks of the San Felipe Marine Sequence. If so, part of unit Tpf might correlate with the Pliocene Salada Formation of the Cañon Las Cuevitas area. One puzzling aspect of any such correlation is that extensive pumiceous material is found in both the Salada Formation and in the Pliocene sedimentary rocks of the Puertecitos Formation. The Santa Rosa basin lies in between these two regions, but no pumiceous material has been reported within it. This would either suggest different timing of deposition in these different basins, or separate volcanic sources in the areas to the $\mathrm{N}$ and $\mathrm{S}$, with no Pliocene volcanic material reaching the region of the Santa Rosa Basin. Possibly, the pumice lapilli were widely dispersed by sea, and did not accumulate in distal, nonmarine basins, such as the alluvial fan sequences of the Santa Rosa Basin.

\section{Structural Controls on Basin Deposits}

In general, Bryant (1986) divided the sequences in the basin according to perceived source and tectonic environment. He felt that Sequence 1 was deposited during tectonic quiescence and derived from more distal sedimentary sources, whereas Sequence 2 was deposited during a time of tectonic activity. This is consistent with the observations of contemporaneous local volcanism, the relative immaturity of the sediments, and the presence of monolithologic megabreccias with basement clasts, above $\mathrm{Tmr}_{1}$ in the lower part of Sequence 2. The unconformity between Sequences 2 and 3 indicates considerable tilting of the basin section prior to sometime in Pliocene time.

The base of $\mathrm{Tmr}_{1}$ usually lies on the sediments of Sequence 1. Less commonly it lies on basement, or on local basaltic lavas of Sequence 2. Because of the limited nature of rocks which underlie it, and the extent of the $\mathrm{Tmr}_{1}$ outcrops, $\mathrm{Tmr}_{1}$ seems to have been deposited on a relatively subdued topography in the Santa Rosa Basin. The proposed $\mathrm{Tmr}_{1}$ correlation mentioned in the previous section would not change this conclusion. Bryant (1986) noted the absence of basalt beneath $\mathrm{Tmr}_{1}$ in some exposures, and attributed this to (presumably minor) erosion.

The upper part of $\mathrm{Tmr}_{1}$ also appears to have been eroded, prior to deposition of younger alluvial 
units. This is suggested by two independent observations. First, the characteristic symmetric zonation one would expect in welded tuffs, with the welding decreasing upsection, was not preserved in $\mathrm{Tmr}_{1}$. Second, Bryant's mapping suggests that in one region, $\mathrm{Tmf}_{1}$ was deposited directly on basement, with Tos and $\mathrm{Tmr}_{1}$ wedging out into the contact in a pattern suggestive of post-Tmr ${ }_{1}$ erosion rather than variations in basement relief. Although there is no major angular unconformity within Sequence 2 , it contains these two erosional unconformities, and probably others (e.g., causing $\mathrm{Tmr}_{2}$ to be eroded). The amount of time that might be represented by erosion of the top of $\mathrm{Tmr}_{1}$ is not well constrained but may be no more than a few m.y. if the relative ages of $\mathrm{Tmr}_{1}$ and $\mathrm{Tmr}_{2}$ are correct.

The change in sediment provenance after Sequence 1 time is very important for understanding the structural evolution of this region. Pre$15 \mathrm{Ma}$ conglomerates of Sequence 1 appear to have been derived from the east, from a region in Sonora. Directional indicators are lacking in $\mathrm{Tmf}_{1}$, but younger units in the sedimentary section appear to have been derived more locally, from a western source. The first reliable indicators of direction in Sequence 2 were found by Bryant (1986) within $\mathrm{Tmf}_{2}$, suggesting a SW source. Bryant (1986) attributed this change in provenance directions to uplift to the W of the Santa Rosa Basin, and consequent reversal of drainage directions. This uplift is probably related to the development of topography along the Main Gulf Escarpment (San Pedro Mártir fault). Separate constraints from the southern end of this fault suggest that this topography developed sometime between $11 \mathrm{Ma}$ and $6 \mathrm{Ma}$ (Stock and Hodges, 1990). This would be a younger time than is implied by the observations from the Santa Rosa Basin, if the $12.3 \mathrm{Ma} \mathrm{K}-\mathrm{Ar}$ age of $\mathrm{Tmr}_{2}$ is correct.

Bryant (1986) viewed all of Sequence 2 as essentially conformable. Dips in the sedimentary units are somewhat variable but generally range between $20-40^{\circ}$ to the W or NW. Locally some dips are to the SW. These dip variations may be due to the lobate nature of the alluvial fan deposits, and also to local structural disruptions such as minor folds and faults within the basin section. If one considers the entire Sequence 2 to be a uniformly tilted package, tilting would have occurred after $\mathrm{Tmf}_{3}$ deposition, and would have been oriented down to the W or NW. Angular unconformities of only a few degrees, indicative of growth faulting and syndepositional tectonism, are known from the Late Miocene volcanic/sedimentary section to the SW and S, in Valle Chico and the Sierra San Fermín (Stock and Hodges, 1990; Stock, 1993; Lewis, 1994). Similar subtle unconformities might be present in the Santa Rosa Basin section, but would be very difficult to identify with the current level of mapping here. The lack of notable unconformities in Sequence 2 suggested to Bryant (1986) deposition in a nearly horizontal, floored graben with a $\mathrm{N}$ to NE-oriented axis (based on paleocurrent directions).

\section{Santa Rosa Basin Detachment Fault}

A low-angle or detachment fault forms the western limit of the mapped exposures of the Pliocene fanglomerates (Tpf) of Sequence 3 (Fig. 8 ). This fault dips $18-22^{\circ}$ and strikes NE to NNE where exposed in arroyo cuts in the region. Striae preserved in clayey surfaces within the fault zone suggest a roughly SE slip direction.

The detachment fault is characterized by slices of brecciated basement lithologies, and tectonic breccias with clasts and blocks of basement rocks, separated by anastomosing fault surfaces. The principal fault zone commonly corresponds to a clay gouge zone $\sim 20 \mathrm{~cm}$ thick. This may be green or red in color and is commonly calcite-cemented. Bryant (1986) did not report striations from the fault zone although he inferred a general transport direction to the southeast. Our reconnaissance observations indicate weak striae, variable in direction, ranging from $E$ to $S E$ to $S$, at several points along the fault zone. The maximum horizontal separation on the fault was estimated to be $\sim 5 \mathrm{~km}$ (Bryant, 1986) based on probable down-dip separation between $\mathrm{Tmr}_{1}$ in the hanging wall and rocks inferred to be correlative with it in the footwall.

Strata mapped by Bryant as Tpf, in the hanging wall of the fault, dip $\sim 20^{\circ}$ or more into the fault zone. They also coarsen significantly as one approaches the fault zone, suggesting that the fault was active during deposition of part of the upper facies of the basin. The units below Tpf are nowhere observed to be in direct contact with the detachment fault.

The $20-40^{\circ} \mathrm{NW}$ to $\mathrm{W}$ tilt of the basin units is problematic. If these units were deposited prior to motion on the detachment fault, and if the detachment fault was only active during Tpf deposition, then another mechanism is required to explain the tilting that occurred before the deposition of Sequence 3. This may partly just be due to the overall tilt of the Sierra San Felipe, as its volcanic cover rocks appear to dip $\mathrm{W}$ in a fairly uniform fashion along the $\mathrm{E}$ side of Valle de San Felipe, and some of this tilting occurred prior to 6 Ma (Stock and Hodges, 1990). However, if the major basal volcanic unit in this part of the Sierra San Felipe is actually all the same welded tuff, as discusssed above under "Regional Correlations of Units," then intervening faults within the range are required in order to allow several parallel, N-S 
bands of W-tilted tuff to have been preserved at similar elevations.

\section{Recent Structural Evolution}

High-angle faults striking NE to ENE displace the strata within the Santa Rosa Basin. None of these are mapped in the vicinity of the detachment fault. However, the geometry of the basal Tertiary unconformity around the margins of the basin (Bryant, 1986), suggests that the detachment fault was displaced by these younger faults.

Many of the ENE-striking faults have sinistral offsets in map view. The most prominent of these fault zones strikes $\mathrm{N} 60^{\circ} \mathrm{E}$ to $\mathrm{N} 80^{\circ} \mathrm{E}$ at the southern end of the basin, and has an apparent left-lateral offset of roughly $2 \mathrm{~km}$ of the basal Tertiary unconformity and all higher units through the base of $\mathrm{Tmf}_{3}$ (Bryant, 1986). However, because the basin strata here dip roughly $20^{\circ} \mathrm{W}$, this offset could have been caused by vertical slip of $\sim 750 \mathrm{~m}$ of the block on the south side of the fault zone, or some combination of sinistral and south-side-down displacement. Bryant (1986) reported striations plunging $30^{\circ}$ in this zone, suggesting that the sinistral component of slip was dominant.

ENE-striking, sinistral faults are regionally important to the south, in the Sierra San Fermín and El Coloradito areas, because they accommodate dextral shear and appear to have caused clockwise rotations of the magnetization directions in pre-3 Ma rocks (Lewis and Stock, 1996). If this family of faults in the SRB is indeed predominantly leftlateral, then this may be another important location where clockwise paleomagnetic rotations would be expected. Further studies of the post-detachment faults and paleomagnetism of the Santa Rosa basin are needed to resolve this issue.

Minor NNW-striking faults with apparent dextral offsets also displace the volcanic and sedimentary units in the Santa Rosa Basin. These faults may be conjugate to the ENE-striking sinistral faults noted above.

\section{THE PUERTECITOS FORMATION}

The Puertecitos Formation comprises the next major set of Miocene and Pliocene marine deposits found on the east coast of Baja California, south of the Santa Rosa Basin region. The Puertecitos Volcanic Province is best known for varied and voluminous nonmarine volcanic units, which dominate its stratigraphy, and range in age from Miocene to Recent (Martín-Barajas and others, 1995). However, on the coast, these interfinger with a series of marine deposits, providing unique timing constraints and paleoshoreline information for this part of the Gulf of California for latest Miocene and Pliocene time. Marine and volcanic units included within the proposed Puertecitos Formation (Martín-Barajas and others, in press) are found along the coast of NE Baja California between latitudes $30^{\circ} 38^{\prime}$ and about $30^{\circ} \mathrm{N}$, and are well exposed on the coastal plain north of Puertecitos (Fig. 9).

\section{Overall Stratigraphy}

The proposed Puertecitos Formation consists of two westward -thinning, wedge-shaped, transgressive-regressive marine sequences less than $100 \mathrm{~m}$ thick each (Fig. 10). These interfinger laterally westward with nonmarine volcanic units. These sequences are separated by the Tuff of Valle Curbina (the lowermost large pyroclastic flow deposit of the Pliocene ignimbrite sequence, dated at 3.27 Ma [Martín-Barajas and others, 1995]). Two major volcanic packages of the PVP in this region are: 1) a late Miocene ( 6 Ma) Tuff of El Canelo, and voluminous late Miocene rhyolite domes (Tmr), and 2) a series of Pliocene ( $3 \mathrm{Ma}$ ) ignimbrites and reworked volcaniclastic units (Fig. 10). The Tuff of El Canelo (Tmc) and the rhyolite flows (Tmr) predate all known exposures of the marine units in this region, but the Pliocene ignimbrites (Tpr) are contemporaneous with the upper half of the Puertecitos Formation. To the south the Pliocene volcanic units dominate the stratigraphic sections, whereas northward the two marine sequences dominate, and contain the distal volcaniclastic facies.

The lower Matomí Mudstone Member is best exposed in the range front bordering the Matomí alluvial fan. The type localities are in Valle Curbina and Arroyo La Cantera (Figs. 11 and 12). The upper sequence is the Delicias Sandstone Member. The stratotype is a composite section with a lower part well exposed in Arroyo Canelo, and an upper part best exposed in the marine terrace of Campo Cristina (Figs. 13 and 14).

\section{General Facies Description}

The Puertecitos Formation exhibits sedimentological characteristics of a shallow marine, intertidal to subtidal environment, with local progradation of alluvial fan and fan delta deposits derived from the west. The facies define subparallel narrow belts along the present range front east and south of the Sierra San Fermín and in the northeastern range front of the Sierra Santa Isabel (Fig. 9). The coarsegrained facies extends less than $400 \mathrm{~m}$ eastward, is less than $70 \mathrm{~m}$ thick, and rapidly interfingers with the muddy sandstone facies in the upper member. Fine-grained deposits to the east are thicker than coarse-grained deposits adjacent to the range front. 

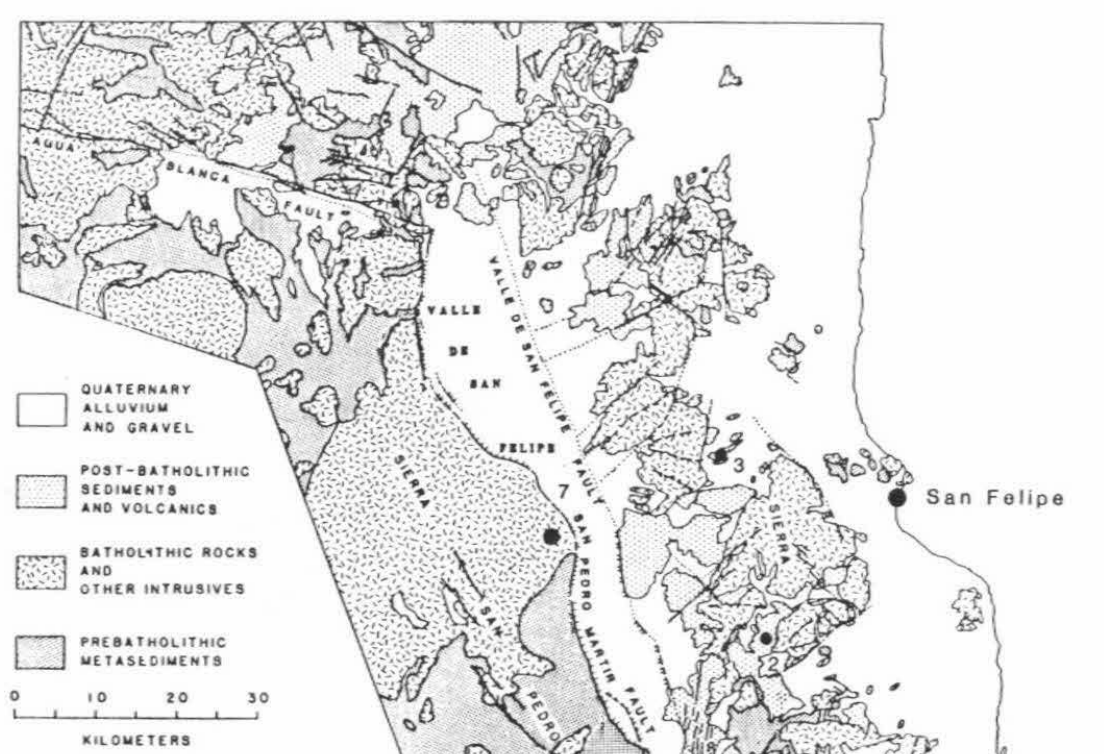

KH OUETERS
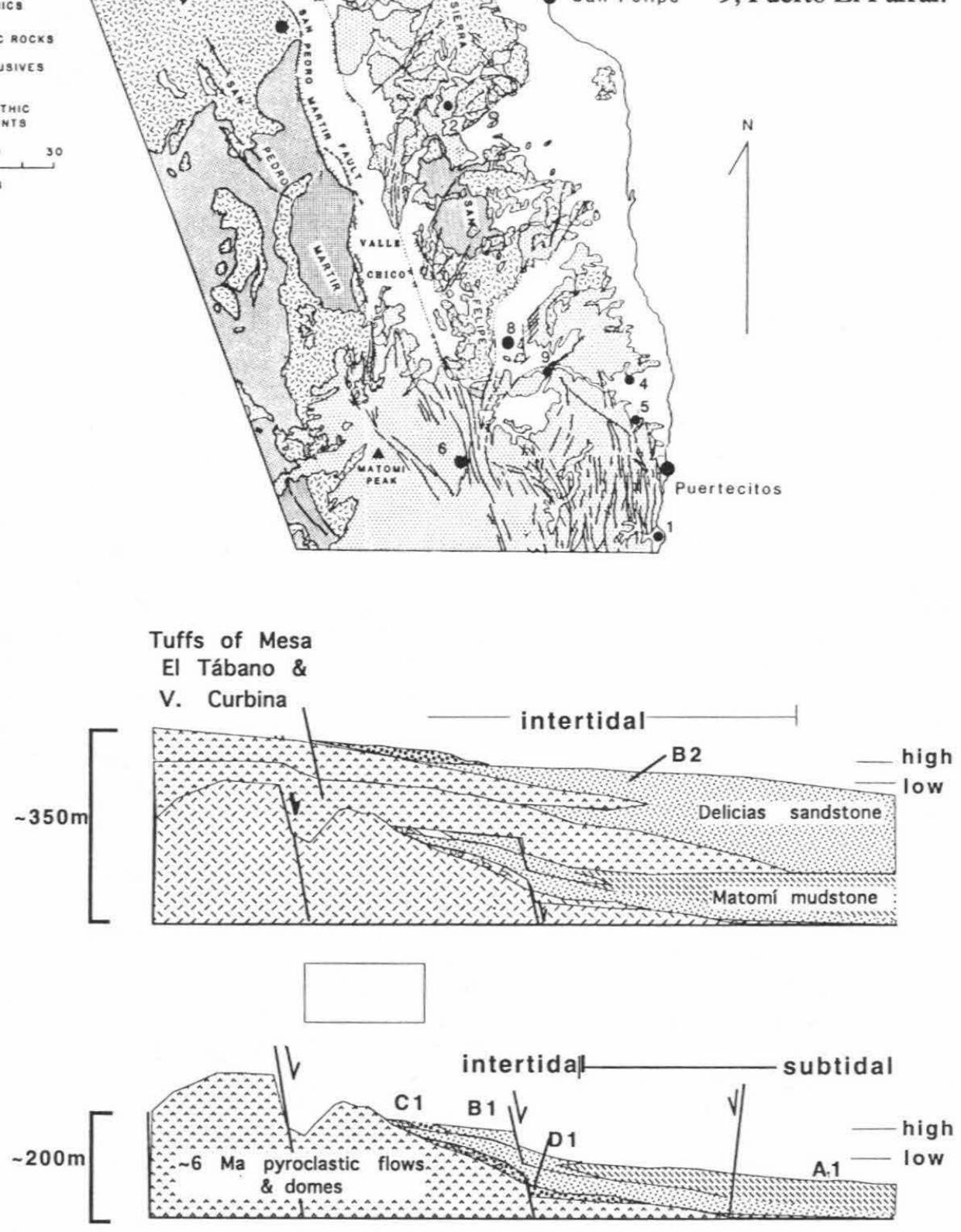

Figure 10. Two-stage schema of the volcanic and sedimentary succession in the northeastern PVP. a) Geologic setting in the lower member: a transgressive-regressive sequence over the $\sim 6 \mathrm{Ma}$ old rhyolite sequence. b) The Tuff of Valle Curbina and the Tuff of Mesa el Tabano are coeval with the upper Sandstone Member. See Table 2 for facies description. Approximate horizontal scale of the section is $4 \mathrm{~km}$. 
Characteristic lithofacies are summarized in Table 2. Muddy subtidal to intertidal deposits (lithofacies A1, A2, B1 and B2) dominate the lower part of both members. Facies A1 likely represents fine-grained deposits in a shallow subtidal setting, below wave base under storm conditions. Its association with fossiliferous muddy sandstone beds (facies B1) suggests shoaling conditions in the intertidal zone. The presence of coarse-grained massive sandstone and gravelly deposits (facies D1) locally interstratified within facies A1 may indicate sediment gravity flows (slumps) possibly associated with normal faulting. Facies B2 is similar to facies B1 in that both correspond to intertidal environments. However, two important distinctions are: 1) facies B2 has fewer fossils and less bioturbation, and 2) the lithological composition. Facies B2 locally includes bivalve mollusk banks (oysters and clams), whereas facies B1 is typically fossiliferous and highly bioturbated.

Coarse grained facies $\mathrm{C} 1$ is well exposed in the Arroyo La Cantera section, and underlies the Tuff of Valle Curbina, a key volcanic unit that marks the top of the lower section (Figs. 10 and 11). Facies C1 typically displays parallel and low-angle planar cross-stratification in sandy to gravelly conglomeratic deposits. It likely indicates wave transport in a beach environment. The transitional contact between facies B1 and facies C1 indicates progradation of the coastline from subtidal to intertidal and into subaerial deposits.

In the El Coloradito area (Fig. 12), the basal unit is a clast-supported conglomerate (facies E1) with characteristics of both gravity flow deposits and a pebbly to bouldery rocky shore line. The facies is massive, with $<10 \%$ matrix. The clasts are poorly sorted, and include mainly sub-angular to subrounded pebbles, boulders of welded tuff and rhyolite lava. However, clasts are roughly imbricated and dip to the east, suggesting wave transport. The matrix between clasts is composed of calcareous hash, mostly from sand dollars. These characteristics suggest reworking in a rocky shoreline; however, no typical fossils (e.g. balanus) or boring traces

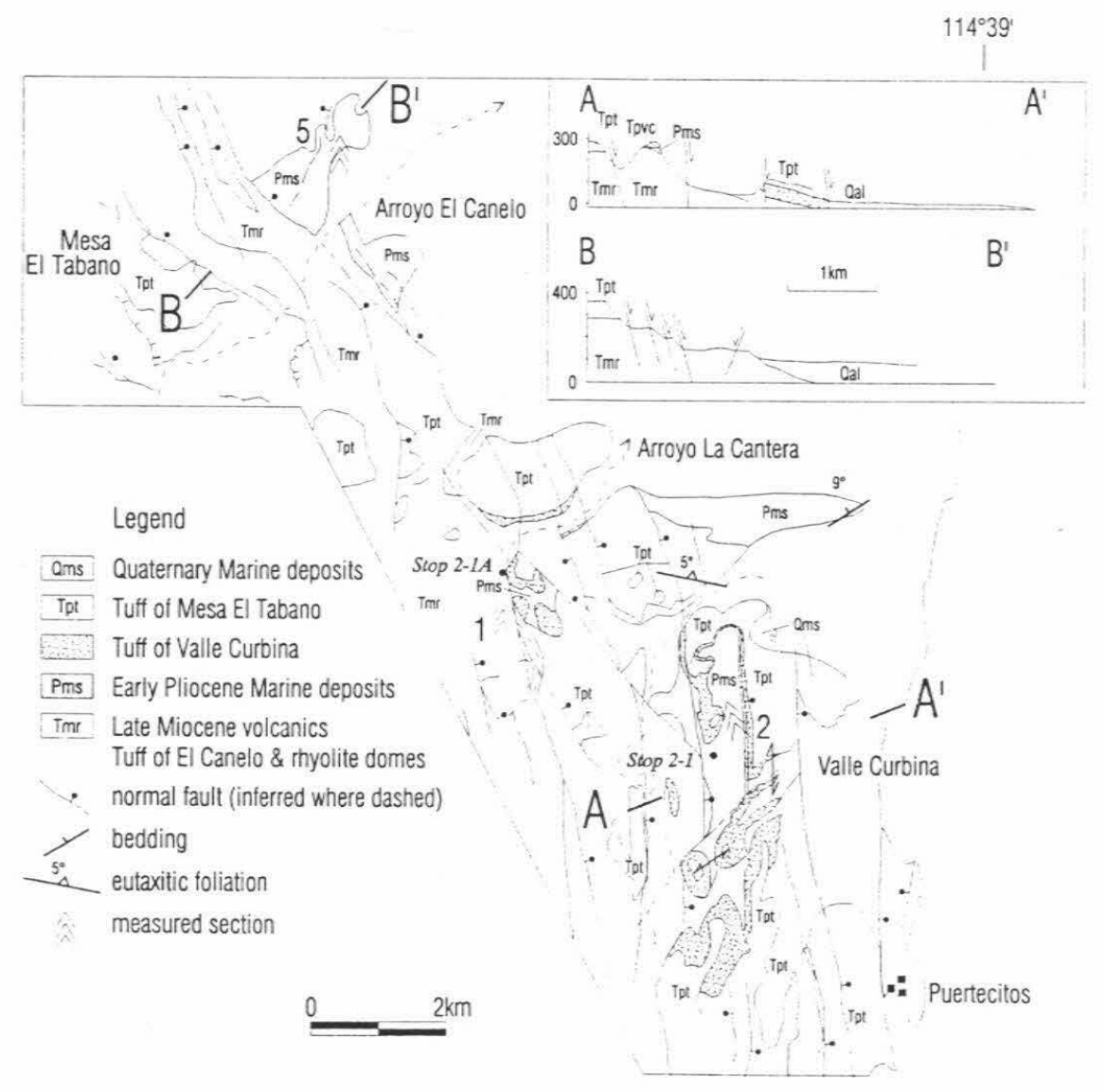

Figure 11. Simplified geologic map of the NE Puertecitos volcanic province (from Martín-Barajas and others, in press). 


\begin{tabular}{|c|c|c|c|}
\hline facies & lithofacies description & $\begin{array}{l}\text { associated } \\
\text { lithofacies }\end{array}$ & interpretation \\
\hline facies A1 & $\begin{array}{l}\text { Yellow-ocher to greenish gray mudstone, massive } \\
\text { to thinly laminated. Up to } 90 \% \text { clay and silt, } 5 \text { to } \\
10 \% \text { of fine sand. Mostly glass, lithic volcanic, } \\
\text { and plagioclase, traces of pyroxenes, opaques and } \\
\text { biotite. Smectite }>>\text { illite in the clayey fraction. } \\
\text { Gypsum-anhydrite and halite are common, both as } \\
\text { a cement in the muddy matrix and as fracture- } \\
\text { filling material. Fossils are scarce, worm tubes and } \\
\text { bivalve shell molds locally found. Few reworked, } \\
\text { and poorly preserved benthic foraminifera. }\end{array}$ & $\begin{array}{l}\text { Commonly in } \\
\text { transitional contact } \\
\text { with facies B1 and } \\
\text { E1. }\end{array}$ & $\begin{array}{l}\text { Shallow, low energy } \\
\text { subtidal deposits below } \\
\text { the wave base under } \\
\text { storm conditions. } \\
\text { Inner to outer platform. }\end{array}$ \\
\hline facies A2 & $\begin{array}{l}\text { Reddish, massive to crudely laminated sandy } \\
\text { mudstone, with lens ( }<15 \mathrm{~cm} \text { thick) of coarse } \\
\text { volcanic sandstone and gravel. Abundant iron } \\
\text { oxide (limonite and goethite). Lenses and beds of } \\
\text { coarse bioclasts (mainly oysters) in a sandy to } \\
\text { muddy matrix. The valves are both complete and } \\
\text { fragmented. }\end{array}$ & $\begin{array}{l}\text { Commonly in sharp } \\
\text { contact with facies } \\
\text { A1, facies B2 and } \\
\text { C2 in the Sierra San } \\
\text { Fermín. }\end{array}$ & $\begin{array}{l}\text { May represent hiatuses } \\
\text { or local unconformities } \\
\text { within the section. } \\
\text { Coarse volcanic and } \\
\text { bioclasts probably } \\
\text { concentrated as lag or } \\
\text { residual material. }\end{array}$ \\
\hline facies B1 & $\begin{array}{l}\text { Yellow to brown-beige, fossiliferous, muddy } \\
\text { sandstone. Variable thickness of beds (few cm to } 1 \\
\text { m), graded and parallel bedding. Pervasive } \\
\text { bioturbation (tubes) in thick strata and lack of } \\
\text { distinct bedding. Sand-sized particles are mainly } \\
\text { bioclastic fragments, devitrified to fresh volcanic } \\
\text { glass and volcanic lithic fragments, and } \\
\text { plagioclase. Carbonate and gypsum cement locally } \\
\text { important. Both primary and reworked shell banks } \\
\text { of molluscan bivalves, gastropods, brachiopods, } \\
\text { echinoderms and arthropods (Table 2). }\end{array}$ & $\begin{array}{l}\text { In transitional } \\
\text { contact with facies } \\
\mathrm{A} 1 \text {, and } \mathrm{E} 1 \text {. }\end{array}$ & $\begin{array}{l}\text { Intertidal to shallow } \\
\text { subtidal deposits above } \\
\text { wave base. Panopea sp. } \\
\text { is a good bathymetric } \\
\text { indicator, living } \\
\text { between the intertidal } \\
\text { zone and } 20 \mathrm{~m} \text { depth. }\end{array}$ \\
\hline facies B2 & $\begin{array}{l}\text { Couplets of sandstone and mudstone in thin beds } \\
\text { interbedded with thicker, massive beds of muddy } \\
\text { sandstone and well-sorted sandstone. The couplets } \\
\text { show sharp bases and ripple cross-laminations and } \\
\text { flaser structures within laminated mudstone layers. } \\
\text { The sandstone beds show poorly planar parallel } \\
\text { laminations and thin beds that frequently contain } \\
\text { lenses of coarse lithic sand and bioclasts. Transport } \\
\text { direction from asymmetric ripple crest in couplets } \\
\text { is NE-SW in El Coloradito and Campo Cristina } \\
\text { (Fig. 4b). }\end{array}$ & $\begin{array}{l}\text { Associated in sharp } \\
\text { contact with facies } \\
\text { A2 C2, and D2. }\end{array}$ & $\begin{array}{l}\text { Intertidal plain } \\
\text { deposits, and sand bank } \\
\text { deposits. }\end{array}$ \\
\hline facies C1 & $\begin{array}{l}\text { Coarse sand and sandy to pebbly conglomerate } \\
\text { beds. Parallel stratification, planar-tabular and low } \\
\text { angle crossbedding (see figure } 4 \mathrm{a}) \text {. Variable bed } \\
\text { thicknesses }(2-20 \mathrm{~cm}) \text {. Large to medium sized, } \\
\text { well rounded to angular cobbles and pebbles in a } \\
\text { poorly cemented, sandy matrix. Rock fragments } \\
\text { are mainly rhyolite lava, and minor welded and } \\
\text { unwelded tuff and pumice. Sand-sized lithic } \\
\text { fragments }>>\text { volcanic glass }>\text { plagioclase. Shell } \\
\text { fragments common. }\end{array}$ & $\begin{array}{l}\text { In gradational } \\
\text { contact with facies } \\
\text { B1. In sharp contact } \\
\text { with co-ignimbrite } \\
\text { ash fall (c.f. figure } \\
\text { 12a). }\end{array}$ & $\begin{array}{l}\text { Sandy to pebbly, beach } \\
\text { face deposit. }\end{array}$ \\
\hline
\end{tabular}

Table 2. Lithofacies description and interpretation of the Puertecitos Formation (after Martín-Barajas and others, in press) 


\begin{tabular}{|c|c|c|c|}
\hline facies C2 & $\begin{array}{l}\text { Grey, sandy -to pebbly conglomerate in laterally } \\
\text { discontinuous, lens-shaped beds. Sharp bases, } \\
\text { trough and parallel cross bedding, and normal } \\
\text { grading. Contains bioclast and intraclast of muddy } \\
\text { sandstone. }\end{array}$ & $\begin{array}{l}\text { Laterally inter } \\
\text { fingers, in sharp } \\
\text { contact with facies } \\
\text { B2, and more rarely } \\
\text { with A2. Associated } \\
\text { with Pap (Ptf) in } \\
\text { Campo Cristina. }\end{array}$ & $\begin{array}{l}\text { May represent fan-delta } \\
\text { channeled deposits, } \\
\text { and/or tidal channels. }\end{array}$ \\
\hline facies D1 & $\begin{array}{l}\text { Yellow to brown color, matrix supported pebbly } \\
\text { conglomerate (diamictite) and poorly sorted coarse } \\
\text { sand, massive beds. May show bioturbation. } \\
\text { Clayey-silty matrix with sand-sized lithics and } \\
\text { minor crystals. Bed thickness from } \sim 0.1 \text { to } 1 \mathrm{~m} \text {. . } \\
\text { Pebbly to coarse-sand sized volcanic clasts } \\
\text { >bioclasts. }\end{array}$ & $\begin{array}{l}\text { In gradational } \\
\text { contact with facies } \\
\text { B1 in Valle } \\
\text { Curbina. }\end{array}$ & $\begin{array}{l}\text { Gravity flow (slump) } \\
\text { deposits, probably } \\
\text { related to } \\
\text { synsedimentary } \\
\text { faulting and tilting. }\end{array}$ \\
\hline Facies D2 & $\begin{array}{l}\text { Alternate thick beds }(10-40 \mathrm{~cm}) \text { of clast-supported } \\
\text { massive sedimentary breccia, and clast-supported } \\
\text { to matrix-supported bedded conglomerate, with } \\
\text { planar and low-angle cross-bedding. Rock } \\
\text { fragments are angular volcanic rocks and very } \\
\text { minor granitic rock fragments. Matrix (if present) } \\
\text { is composed of coarse sand. }\end{array}$ & $\begin{array}{l}\text { This facies laterally } \\
\text { interfingers with } \\
\text { lithofacies B2 and } \\
\text { unconformably } \\
\text { overlies and is } \\
\text { juxtaposed in fault } \\
\text { contact with granitic } \\
\text { and/or volcanic } \\
\text { rocks. }\end{array}$ & $\begin{array}{l}\text { Proximal colluvial } \\
\text { deposits associated } \\
\text { with faulted range } \\
\text { front. Laterally passing } \\
\text { into intertidal inlet and } \\
\text { plain. }\end{array}$ \\
\hline facies E1 & $\begin{array}{l}\text { Poorly bedded, clast-supported conglomerate, with } \\
\text { imbricated cobbles and boulders. Subangular to } \\
\text { rounded clasts, clast imbrication. Matrix, where } \\
\text { present, is chiefly calcareous hash of sand dollars. } \\
\text { Exclusively volcanic rock fragments. }\end{array}$ & $\begin{array}{l}\text { Basal conglomerate } \\
\text { over volcanic ramp- } \\
\text { like basement } \\
\text { (major } \\
\text { unconformity). In } \\
\text { gradational contact } \\
\text { with facies B1. }\end{array}$ & $\begin{array}{l}\text { Rocky (boulder to } \\
\text { pebbly) shoreline } \\
\text { deposits, based on clast } \\
\text { imbrication and matrix. } \\
\text { However, no encrusting } \\
\text { or boring organisms } \\
\text { present. }\end{array}$ \\
\hline
\end{tabular}




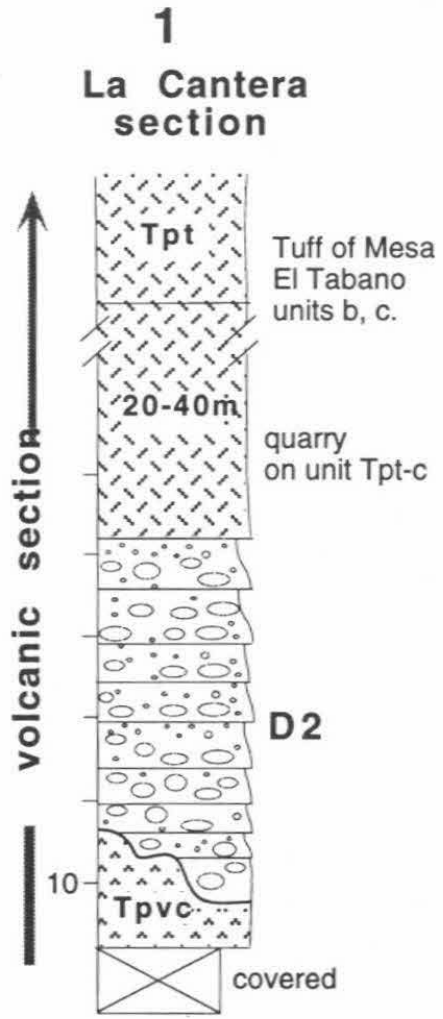

\section{2 \\ Valle Curbina section}
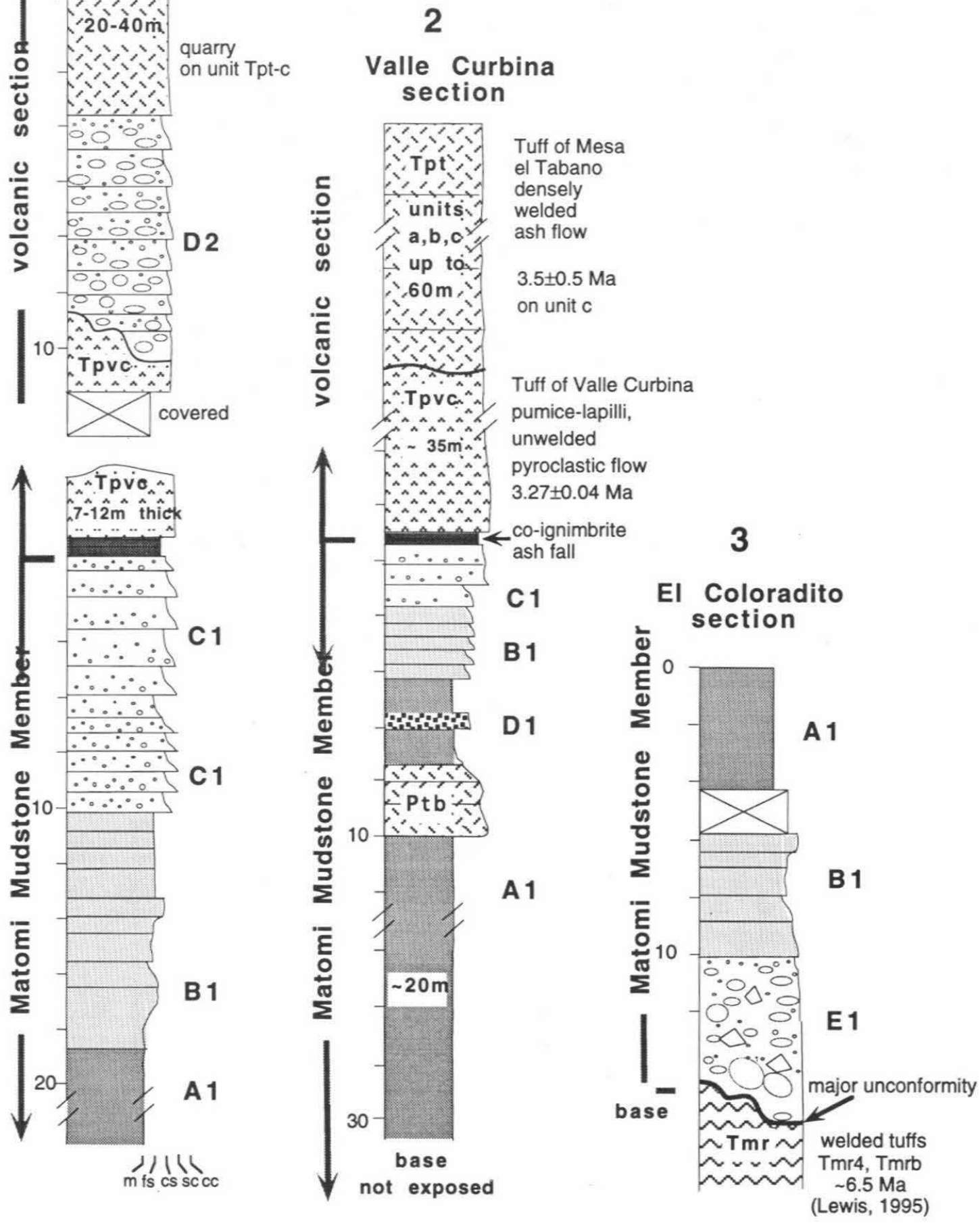

Figure 12 Stratigraphic logs of the lower Matomí Mudstone member, Puertecitos Formation. Logs 1 and 2 corresponds to alternate stop $2.1 \mathrm{~A}$ and stop 2.1 , respectively. 
Figure 13. Simplified geologic map of the eastern margin of Sierra San Fermín and outcrops of the upper Pliocene Delicias sandstone member beneath Plio-Quaternary alluvium (modified from Rebolledo-Vieyra, 1994). Measured section 4 is the type locality of the upper section (see figure 14).

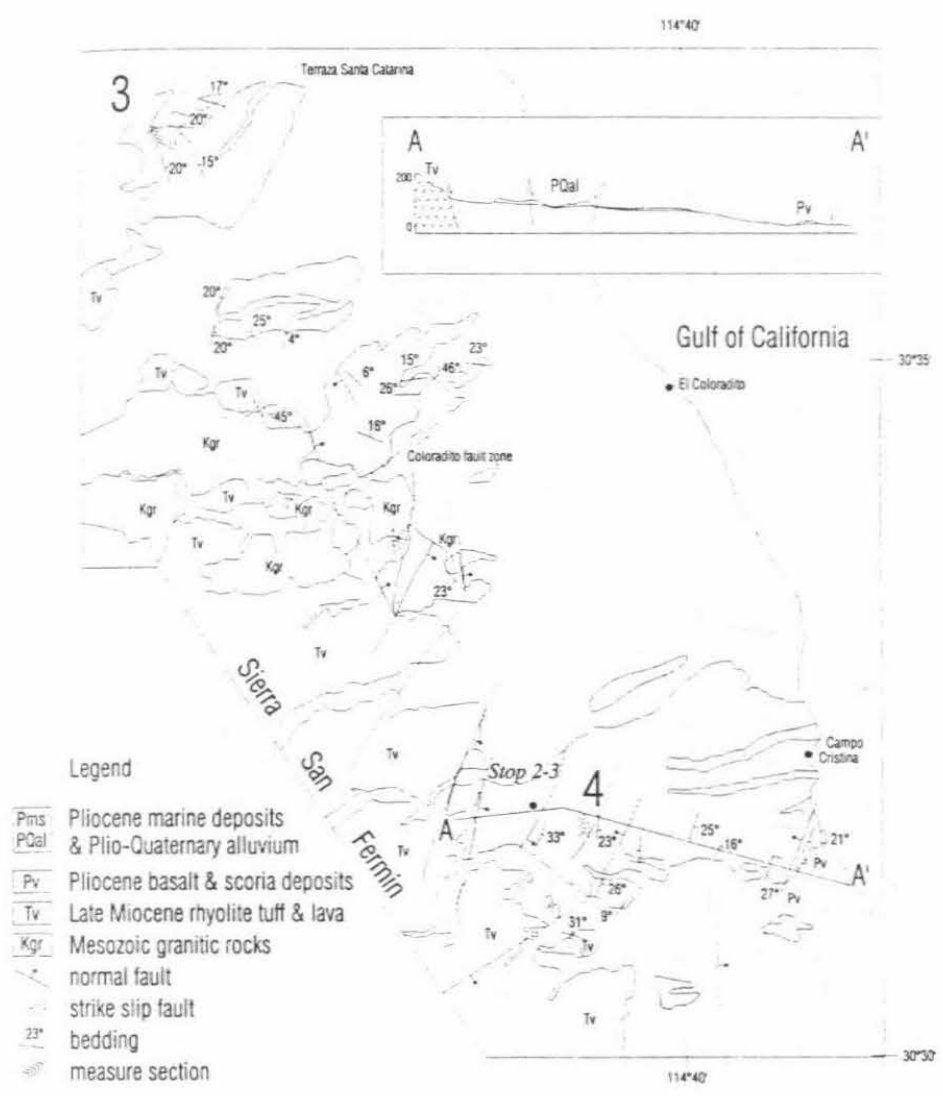

(Tripanites ichnofacies) were observed. Our preferred interpretation is that facies E1 is an incipient rocky shoreline. Its association with facies B1 suggests a transgressive event and shift into a sandy-muddy substrate in intertidal conditions.

Facies A2 is a reddish to yellowish, poorly laminated, sandy mudstone. It contains contorted laminations, and lenses of reworked oyster shells. Coarse sand and gravel is present in the form of irregular lenses or "pods". The matrix is strongly oxidized to limonite-goethite. Its association with facies A1 and A2, along with strong oxidation, suggests intervals of subaerial exposure, accompanied by erosion and residual concentration of coarse sediments and diagenetically formed minerals. Facies A2 may mark hiatuses in the sequence.

The intertidal facies B2 lies in sharp contact with facies $\mathrm{C} 2$ which likely represent coarse intertidal channel deposits or channeled deposits in
Figure 14. Composite stratotype of the Delicias Sandstone member. Location of $\log 4$ and 5 in figures 11 and 13 , respectively. See text for description of sedimentary facies and volcanic units. Isotopic ages from Martín-Barajas and others (1995).

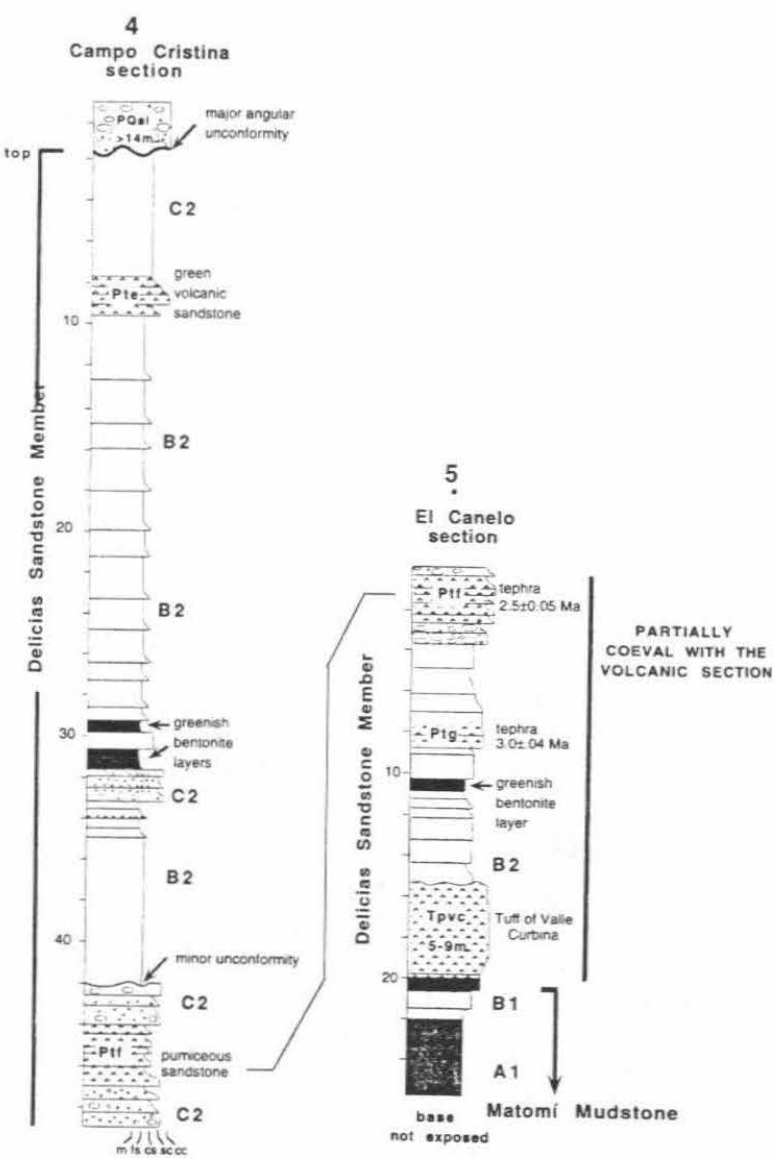

a progradational fan delta body. The laterally discontinuous shape of the beds and the presence of rip-up clasts of muddy sandstone suggest intertidal channel deposits.

The upper part of the Puertecitos Formation locally includes conformable alluvial deposits that consist of sandy to gravelly conglomerates, both matrix supported and clast supported, that normally represent progradation of the shoreline during low sea-level stands. Nevertheless, in most marine terraces east of Sierra San Fermín the upper conglomerate lies in angular unconformity over the upper member, which is normally tilted $20^{\circ}$ to $30^{\circ}$ to the east.

\section{Fossil Assemblage}

The fossil assemblage of the Puertecitos formation is compatible with a warm, shallow-water environment, similar to the modern Gulf. The most 
diverse macrofossil assemblage was found in the muddy sandstone facies (facies B1) from the Arroyo La Cantera section (alternate stop 2.1B, see Fig. 11). In this area 24 species were identified, of which 11 are bivalve mollusk and 10 are gastropods, 1 is brachiopod, 1 echinoderm and 1 cirripedium (Martín-Barajas and others, in press). Pervasive bioturbation, encrusting organisms (e.g. balanus) and rock-boring ichnofossils are also common in facies B1. Molds of Chione $s p$. are locally abundant in the yellow mudstone facies which also contains thin irregular tubes (1-2 mm diameter) of bioturbation. The overall fossil assemblage corresponds to a warm shallow marine environment $(0-20 \mathrm{~m})$ with a muddy to muddy-sandy substrate.

The Turritella $\mathrm{n} \mathrm{sp}$. is abundant and it is similar to Turritella planigyrata, but the former has a thicker rolling pattern. This fossil may be considered distinctive of the Puertecitos Formation since it was found in both members. Another probable endemic species is Dosinia n. sp. which is similar to Dosinia cf. ponderosa but is smaller in size and has thicker growing lines. Dosinia $n$. $s p$. was only observed in the upper Delicias Sandstone Member. These two species Turritella n. sp. and Dosinia n. sp. may be considered endemic species of the Puertecitos area, since they have not been reported in other circum-Gulf Late Neogene sequences (e.g. Smith, 1991; Bell-Countryman, 1984; Hertlein, 1968). The echinoderm Panopeas sp. constrains water depth to less than $20 \mathrm{~m}$ (Keen and Coan, 1974). It was found in life position suggesting that this sandy-muddy lithofacies was below the wave base. However, reworked fossils are abundant in the upper part of the lower member suggesting shoaling conditions.

Upward the sequence coarsens and contains Encope sp cf chaneyi in life position. This fossil is reported to live at a maximum depth of $30 \mathrm{~m}$, but is very common in the lower intertidal zone (Morris, 1980). Thus, this fossil represents the subtidalintertidal transition. Its association with encrusting organisms (Balanus $\mathrm{sp}$ ) and vertical tubes of bioturbation distinctive of the skolithos ichnofacies is also consistent with shoaling conditions and progradation of the coastline.

Calcareous microfossils are sparse in the Puertecitos Formation. Microfossils are recrystallized and poorly preserved due to diagenesis. However, the specimens that were identified indicate shallow marine environments, specifically the ostracod Perissocytheridea meyerabichi which is typical of tidal flats and eulittoral zones (Ana Luisa Carreño, written communication, 1994). Perissocytheridea meyerabichi and Cyprideis sp. are relatively common in the upper member.
Only two benthic foraminifera were unequivocally identified in the mudstone facies A1 from Valle Curbina: Bulimina sp. and Buliminella $s p$. are indicative of a subtidal to intertidal environment. However, the most common benthic foraminifera found in the fine grained facies of the Puertecitos Formation is Nonion grateloupi. This fossil is widely distributed in Late Neogene to Recent time and has been found in the neritic environment (A. Carreño, written communication, 1994). Apparently this calcareous microfossil resisted the effects of diagenesis.

\section{Structural Controls on Deposition}

Facies distribution in the Matomí-San Fermín area suggests that the position of the coastline in early Pliocene time was controlled by paleotopography previously developed on $\sim 6 \mathrm{Ma}$ old rhyolite domes and flows. The contact between the volcanic basement and the marine sequence is generally a ramp-like surface dipping from 5 to $15^{\circ}$; locally it is a high-angle fault contact. No buttressed sedimentary sections were observed in the lower member. Thus deposition of the marine beds in the Arroyo Matomí area and in Sierra San Fermín began well after this period of tectonic extension.

During latest early Pliocene time, extensive small-scale synsedimentary faulting produced internal unconformities, and the hiatuses are marked by local angular unconformities, and by the presence of reworked, reddish shell beds and conglomerates in the upper member (Facies A2). The net results were low accumulation rates and condensed sequences during periods of subaerial exposure.

Locally, the upper member includes up to $70 \mathrm{~m}$ of coarse conglomerate and breccia deposits (facies D2) buttressed against Cretaceous granitic rocks in the El Coloradito fault zone (Fig. 13). These deposits are clearly associated with a synsedimentary oblique fault at the range front of the Sierra San Fermín. At the base, the coarse deposits laterally interfinger with the marine muddy-sandstone facies, and upwards the conglomerate progrades over the marine deposits to the east.

A distinctive feature through all the Puertecitos Formation is that clast composition in the Matomí mudstone member is largely dominated by volcanic rocks ( $>98 \%)$. An increase of granitic and metamorphic rocks fragments upwards suggest denudation of the volcanic cover and exposures of the crystalline basement probably as a result of faulting. Another explanation is that basementderived detritus in the upper member records a shift in the drainage paths toward this area in upper late Pliocene time (Martín-Barajas and others, 1993). 
The accumulation rates recorded in the Puertecitos Formation (Rebolledo-Vieyra, 1994; Martín-Barajas and others, in press) are two orders of magnitude less than reported sedimentation rates in the Vallecitos-Fish Creek section in southern California (Johnson and others, 1983) and in the Pliocene Loreto Basin (Umhoefer and others, 1994; Dorsey and others, 1996). This evidence suggests that in the Puertecitos accommodation zone, normal faulting and tectonic subsidence in Pliocene time were relatively small, compared with the large ( $>1$ $\mathrm{km})$ vertical offset in faults that bound the interbasinal mountain ranges to the north (e.g. San Pedro Mártir fault and Laguna Salada fault), which accommodate higher tectonic subsidence in major segments of the GEP. We interpret differences in style of sedimentation to reflect the distinctive structural patterns of the Puertecitos accommodation zone. Probably a higher heat flow and lower subsidence rates may have prevailed in the accommodation zone setting, in comparison with the lack of volcanism and higher tectonic subsidence in basins of rift segments onshore the GEP.

\section{BASIN DEPOSITS AND THEIR RELATION TO TECTONIC DEVELOPMENT OF THE GULF OF CALIFORNIA}

The oldest well-constrained ages on the marine rocks discussed above are $\sim 6 \mathrm{Ma}$ for the San Felipe diatomite member in the San Felipe marine sequence and $<5.5 \mathrm{Ma}$ in the Puertecitos Formation where it overlies dated rhyolite flows. Because the base of the San Felipe marine sequence (Cañon Las Cuevitas Diatomite Member) is not exposed, the maximum age of marine sedimentation in this area is not known. The Santa Rosa basin is older (middle Miocene), and does not contain any marine deposits. The Imperial Formation in Laguna Salada is presumed to be roughly coeval with the other Pliocene marine basins, but age constraints are poor.

To place these basins in their overall context within the Gulf of California rift system, one must recognize that approximately $300 \mathrm{~km}$ of separation has moved this part of Baja California away from its pre-late Miocene position relative to adjacent Mexico. This $300 \mathrm{~km}$ of displacement is constrained by several features in the area of the field trip. First, the pre-15 Ma conglomerate deposit containing Permian fusilinid-bearing clasts, present in the Santa Rosa Basin, was correlated by Gastil and others (1975) with a similar deposit near Bahia Kino, Sonora. Second, pre-Cretaceous sedimentary rocks, which were variably metamorphosed by the Cretaceous Peninsular Ranges batholith, provide facies trends which can be generally correlated across the Gulf of California. Reconstruction of these displacements would place Isla Tiburon approximately next to the coastal area of NE Baja California, south of the town of San Felipe.

Observations of sedimentary rocks, timing of basin initiation and faulting from Isla Tiburon are therefore also quite relevant to our general discussion of the extensional history of the region. On Isla Tiburon, an 11.2 $\pm 1.3 \mathrm{Ma}$ ash flow tuff overlies about $1.5 \mathrm{~km}$ of marine sedimentary rocks with many molluscan species similar to those found in the Imperial Formation in California (Coyote Mtns and San Gorgonio Pass), and similar to those found in the Boleo Formation near Santa Rosalía. This marine sequence contains an interbedded debris

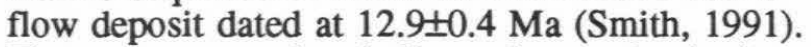
These age constraints indicate that marine basins were present in the Gulf, at approximately this latitude, as long ago as $12 \mathrm{Ma}$. Despite the close paleogeographical proximity of Isla Tiburón and the San Felipe-Puertecitos coastline, the marine sequence from Isla Tiburon is older than any Miocene marine rocks known thus far from NE Baja California or from the Salton Trough.

Other constraints on the tectonic evolution of the Gulf come from the faulting and the depositional histories of the sedimentary sequences visible in these basins. The time of the change in provenance directions from $\mathrm{E}$ to $\mathrm{W}$ in the Santa Rosa Basin and in the Sierra San Fermín is constrained to be sometime between $21 \mathrm{Ma}$ and 9 $\mathrm{Ma}$, if the correlation of units between these two areas is correct. This indicates the development of topography to the west, and the disruption of drainage patterns in the region of the modern Gulf, well before the time of the earliest Gulf marine sedimentary sections known from NE Baja California. It is not known which faults within the extensional province might have been responsible for the change in provenance. Motion on the San Pedro Mártir fault began sometime between $11 \mathrm{Ma}$ and $6 \mathrm{Ma}$ (Stock and Hodges, 1990), but other faults within the extensional province may also have been active at this time, and may have presented a more local source of topography.

The Puertecitos Formation accumulated partly due to slip along east-dipping range-front fault systems, suggesting that these were active by earliest Pliocene time, prior to the $\sim 3 \mathrm{Ma}$ set of volcanic eruptions of the PVP. The next major event in this area was that responsible for the unconformity above the Matomí Mudstone Member of the Puertecitos Formation. This event uplifted the Matomí Mudstone Member in the Arroyo La Cantera and Valle Curbina areas, so that subaerial, densely welded tuffs were deposited unconformably on top of the mudstones. In the marine regime, the Delicias Sandstone Member was deposited above the unconformity. 
This is reminiscent of the unconformity at the base of the Salada Formation in the San Felipe Marine Sequence. Both unconformities are associated with shallowing and a change in provenance, from a volcanic source to a more local source of basement detritus. A comparison of these basins suggests that a single process at or after 3.3 Ma may have been responsible for provenance changes in the coastal areas, including the Puertecitos Formation and the San Felipe Marine sequence, This process could have been coastal uplift due to a change in fault patterns, and/or eustatic changes coupled with a reduction in input of primary and eroded volcanic material to the area. This is particularly likely if the San Felipe Marine Sequence and the Puertecitos Formation had the same volcanic source (the Pliocene eruptions of the Puertecitos Volcanic Province).

Extension on low-angle normal faults in the Laguna Salada area and in the Santa Rosa Basin took place in Pliocene time. Although other lowangle normal faults may be active at depth today within the Gulf Extensional Province, the two faults exposed in these basins are now inactive and cut by younger, often strike-slip, faults.

Sinistral slip on the NE- and ENE-striking faults in the Sierra San Fermín-El Coloradito-Santa Rosa Basin area can be attributed to a stronger component of dextral shear since late Pliocene time (Lewis, 1994). This represents a relatively young structural regime, which may have resulted from a change in tectonism in middle Pliocene time. We hypothesize that this fault pattern may be typical of the young tectonics of the entire Sierra San Felipe area. If so, it represents an attractive candidate for a structural change that might have aided in uplifting and exposing the Pliocene basin sequences of this part of the circum-Gulf region.

\section{ROAD LOG, DAY 1.}

Leave San Diego at 7:30 AM, following US Interstate 8 east across the Peninsular Ranges to the Imperial Valley, California. Take Highway 111 south to Calexico and cross the international border. From Mexicali to the south we will drive on highway 5 . This highway runs N-S along the western margin of the Mexicali Valley, the southern extension of the Salton Trough (Fig. 1). The Mexicali valley extends up to $30-40 \mathrm{~km}$ westward from the margin of the Colorado River. This basin is an important water reservoir for the agricultural economy of the Mexicali Valley, and also provides water to Tijuana by an aqueduct across the Peninsular Ranges.

After crossing the intersection with highway Mex 2, you can look SE to see Cerro Prieto, which lies in a stepover in the transform fault system. As we continue $S$ you may see vapor coming off the geothermal wells of the Cerro Prieto Geothermal Field (CPGF). The geothermal field lies east of one of the transform faults. The subsurface stratigraphy of the geothermal field results from complex vertical and lateral variations of lithofacies in a deltaic environment, and a rapidly evolving basin in a pull-apart setting (Lomnitz and others, 1970; Elders and others, 1972). If the weather is clear, you will be able to see the northern Sierra de Juárez off on the horizon at about 2 o'clock. The basin between the Sierra de Juárez and the nearer Sierra Cucapá is the Laguna Salada Basin.

Sierra Cucapá is the range located west of highway 5 and will be visible to our right as we proceed south. A series of well exposed alluvial fans along the range front host sand and gravel quarries for the local construction industries.

Leave highway 5 at $\mathrm{km} 40$ (Ejido Lopez Mateos), turning onto a dirt road which leads W towards the Sierra Mayor/Sierra Cucapá. RESET ODOMETERS to ZERO as you leave the paved road. Detailed directions for this road will be provided to the drivers (see also Siem and Gastil, 1994).

\section{Stop 1-1.}

$10 \mathrm{~km}(6 \mathrm{mi})$. This stop provides a general view from drainage divide. To the east lies the Mexicali Valley and Cerro Prieto. To the west, you can see the Laguna Salada basin and the Sierra Juárez range front. North of us lie outcrops of gneisses and schists in the southern end of the Sierra Cucapá.

Continue on down the other side of the drainage divide and into Cañada David. You may need 4WD in the sandy part of the arroyo. Shortly after exiting the outcrops of metamorphic rocks, turn right up a side drainage and park.

\section{Stop 1-2. Cañada David detachment.}

$17.9 \mathrm{~km}(11.2 \mathrm{mi})$. At stop 1-2 the Tertiary sedimentary section includes up to $100 \mathrm{~m}$ of claystone, overlying the metamorphic basement in fault contact. The Cañada David Detachment fault (CDDF) is a distinctive black layer that has an average thickness of 0.5 to $1.0 \mathrm{~m}$. This layer is a cataclastically deformed microbreccia also affected by a set of anatomosing low angle conjugate fractures (Siem, 1992). These fractures bound lenses of cataclasite and give the layer a cleaved appearance. The fractures are commonly filled with secondary gypsum (Siem, 1992).

From stop 1-2 to stop 1-3A: hike along the wash north of Nightstalker ridge. We will look at the lower plate metamorphic rocks, chiefly composed 
of garnet-biotite-gneiss, with occasional sillimanite and migmatite gneiss. On the northern flank of the wash, you can see outcrops of the basement shear zone which includes primarily marble and graphitic quartzite rocks (Siem, 1992).

\section{Stop 1-3A. Outcrops of facies 1 (Tim1) of the Imperial Formation.}

The breccia is a few tens of meters thick and grades upwards into coarse grained sandstone and to alternate thin beds of fine grained sandstone and siltstone. Bedding is $\mathrm{N} 70 \mathrm{~W} \backslash 15 \mathrm{~N}$. The sequence is poorly exposed and up section, a few meters to the north, a fault cuts the sequence, juxtaposing the mudstone and sandstone facies. The sedimentary breccia here is correlated with bedded breccia and conglomerate that crops out at Coral Hill located $1.5 \mathrm{~km}$ to the ESE. At Coral Hill bedding is a few $\mathrm{cm}$ to $0.5 \mathrm{~m}$ thick and includes matrix-supported conglomerates. The sandy matrix is reported to contain abundant bioclast debris (Siem, 1992).

\section{Stop 1-3B. Faults within the Imperial and Palm Spring formations.}

From stop 1-3A to stop 1-3B, we will take an easy hike to the west over the alluvial peneplain developed on Imperial and Palm Spring formations. To the NW, on the eastern flank of the Cerro Colorado, the nearby prominent hill, a complete section of Imperial (yellowish) and Palm Spring formations is nicely exposed. The Imperial mudstone facies crops out in a structural window, formed by two N-S striking low-angle normal faults with opposing dips. The eastern, east-dipping fault crops out through the badlands in a N-S direction, along the arroyo which drains the eastern slope of Cerro Colorado.

This fault has a sinuous trace but it is well marked by the color change between the Imperial (yellowish) and Palm Spring (reddish-brown) deposits. It also truncates the distinct bedding of the Palm Spring Formation. The latter is overlain by clast-supported conglomerate in angular unconformity.

Return to Stop 1-2 and continue walking W along the Arroyo Chupamirto to stop 1-3C.

\section{Stop 1-3C. Mudstone facies of the Imperial Formation.}

The mudstone facies of the Imperial Formation here grades upward to silty and fine-grained sandstone with interbedded coquina. Several NWstriking, W-dipping normal and oblique faults disrupt both the Imperial and Palm Spring formations. Further west, we can get a closer view of the faulted contact between the sandy-muddy facies of Palm Spring and the Imperial mudstone facies along the western (west-dipping) low angle normal fault. Here, the Imperial mudstone contains sandy fossiliferous beds and lenses of coquina. The coquina beds are mainly composed of bioclasts of turritelids and oysters.

After Stop 1-3C, retrace the route to Highway 5. Reset odometers to zero where you rejoin the paved road. Turn right, and continue $S$ towards San Felipe. Landmarks along this route include:

$14 \mathrm{~km}(8.8 \mathrm{mi})$-Abarrotes El Chaparral on the E side of the highway.

$19.8 \mathrm{~km}(12.4 \mathrm{mi})$-On the right, you can see the dark metamorphic rocks in the foreground, and the tonalites of the Sierra El Mayor in the background and ahead to the right. There are more terraces visible to the right.

$28.3 \mathrm{~km}(17.7 \mathrm{mi})$-View W around the south end of the Sierra Cucapá, to the Sierra de Juárez- Sierra La Tinaja, the southern end of the Laguna Salada basin.

$30.6 \mathrm{~km}$ (19.1 mi)-As you cross over a canal on the main road, note a series of dirt mounds on the W side of the highway. These mark the canal that was dug in 1984 to connect Laguna Salada with the Gulf of California. Ahead you can see the northern Sierras Pintas, with Paleozoic rocks partially covered by sand dunes.

59.5 km (37.2 mi)-Gas station La Ventana.

$62.3 \mathrm{~km}$ (39.3 mi)- Road passes through Sierras Pintas volcanic rocks.

$92.6 \mathrm{~km}(57.9 \mathrm{mi})$ - Rest area at El Chinero and intersection with Mexican Highway 3 to Ensenada. $105.5 \mathrm{~km}$ (65.9 mi)- View of Picacho el Diablo off to the W. This is the highest peak on the Baja California peninsula (3000 m elevation).

At $128 \mathrm{~km}(80 \mathrm{mi})$, turn right onto a wide, graded dirt road labeled "Col Morelia - El Saltito Spr". This is near a major roadside trailer park and residential development labeled "El Dorado Ranch". Follow this road up to the pass. At 144.3 $\mathrm{km}(90.2 \mathrm{mi})$, turn right onto a side road labeled "Sierra Highlands" and "Oasis Road". Follow this track approximately $1.6 \mathrm{~km}$, staying downslope (east) of the houses, and park in the arroyo near the diatomite mine.

\section{Stop 1-4. San Felipe marine sequence.}

Here, we will hike a short distance to examine the sedimentary facies and fossils of the San Felipe marine sequence. We will look at the basal San Felipe diatomite member and the Cañon Las Cuevitas mudstone member of the Llano El Moreno Formation, and the overlying, fossil-rich, Salada Formation, noting the transition from deeper water to shallower water facies and the numerous small 
faults that disrupt the sequence here. See above for details of the lithostratigraphy and paleontology of this region.

\section{ROAD LOG, DAY 2.}

Leave San Felipe at 7 a.m. and drive south along the paved coastal highway. As you leave town, look to your right (west) at the steep eastern front of the Sierra de San Felipe. This is inferred to be controlled by a now-inactive, east-dipping normal fault (Fenby and Gastil, 1991). This fault would dip E towards the Gulf of California. The isolated granitic hills along the coast, at Punta Estrella, are interpreted to lie in the hanging wall of this fault.

Passing around the E side of Punta Estrella, we continue $\mathrm{S}$ along the coastal road. To your right (W) you can see the Sierra San Felipe. At about km 30 , a crossing dirt road goes left (east) towards Laguna Percebu and right towards Arroyo Huatamote and the Santa Rosa Basin (which we will visit tomorrow, arriving on a different route).

From about $\mathrm{km} 40$ to $\mathrm{km} \mathrm{55,} \mathrm{the} \mathrm{major} \mathrm{range}$ to the W is the Sierra San Fermín. Lewis (1994) mapped the geology of this area and conducted geochronologic and paleomagnetic studies. Major new conclusions from this area include the evidence for significant clockwise rotation of Miocene and Pliocene rocks in this region; the location of the probable source area for a regionally extensive 11 Ma welded tuff; and evidence for the initiation of extension here between $11 \mathrm{Ma}$ and $6 \mathrm{Ma}$. The Sierra San Fermín and regions to the $\mathrm{S}$ and $\mathrm{SW}$ in the Puertecitos Volcanic Province also contain a variety of volcanic rocks (basalts to dacites, and proximal to medial epiclastic sedimentary rocks such as debris flows) from the early to middle Miocene subduction-related volcanic arc.

The coastal terraces at the southeastern end of the Sierra San Fermín were studied by RebolledoVieyra (1994) and will be visited later today on our way back to San Felipe from Puertecitos.

\section{Stop 2-1 Valle Curbina}

This is an easy hike up the canyon, about $1 \mathrm{~km}$ round trip.

Valle Curbina is located $3 \mathrm{~km} \mathrm{NW}$ of

Puertecitos (Figs. 5 and 9). The access to the valley is through a narrow canyon cut into pyroclastic flow deposits. At the entrance to the canyon, three N-S striking west- and east-dipping normal faults cut the volcanic sequence, causing stratal tilts of $10-15^{\circ}$ to the east. As we walk west up the canyon we will thus be going down section into lower stratigraphic levels.

Two welded tuffs (units b and c) of the Pliocene Tuff of Mesa El Tábano lie high on the canyon walls; the Tuff of Valle Curbina (Tpvc) crops out beneath them. Tpvc is the yellowish poorly consolidated pyroclastic flow with abundant pumice-lapilli which is prominent in the canyon walls. Tpvc has $20-25 \%$ phenocrysts, mainly plagioclase (An25-50), biotite, clinopyroxene (diopsidic augite-ferroaugite), and rare hornblende. Lithic fragments (10\%-15\%) are principally rhyolite, with minor andesitic porphyry, basaltic andesite, and granite. This tuff has two type of glass: one type is medium brown in thin section and the other is colorless. Both are rhyolitic, but the brown variety is $1-2 \%$ less silicic and contains $0.5 \%-1 \%$ more iron. Tpvc was dated at $3.27 \pm 0.04 \mathrm{Ma}$ $\left({ }^{40} \mathrm{Ar} /{ }^{39} \mathrm{Ar}\right.$, plagioclase).

The overlying purple-reddish welded tuffs of the Pliocene Tuff of Mesa El Tábano are crystal poor $(<10 \%)$ and contain plagioclase (An20-30), orthopyroxene and clinopyroxene. They lack hydrous phases such as biotite or hornblende. Olivine phenocrysts are fairly common in these rhyolite and dacite rocks. This phenocryst assemblage is characteristic of the Pliocene ignimbrites of the Puertecitos Volcanic Province (Martín-Barajas and others, 1995).

In the canyon walls, you will see well exposed gas pipes with coarse lithic fragments, and numerous fractures filled with silt to gravel-sized sediments, within Tpvc. In Valle Curbina, Tpvc fills topography and has variable thickness, from $\sim 35 \mathrm{~m}$ to as much as $60 \mathrm{~m}$ in the paleotopographic lows. This unit overlies the Matomí Mudstone member of the Puertecitos Formation, described further below.

Valle Curbina is a narrow graben bounded by two east-dipping high angle normal faults. The eastern fault truncated section in the Tuff of Valle Curbina; small fault scarps and fractures on the bedrock suggest recent activity of this fault. The western bounding fault produced a vertical offset of $\sim 80 \mathrm{~m}$ and cut the marine sequence and the rhyolite dome; both units crop out in the footwall block. The fault plane is easily recognized on the northern side of the dome, by the whitish color produced by fibrous gypsum and calcite over the fault plane.

Coarse beach deposits thin and pinch out over the rhyolite dome. To the east the conglomeratic deposits pass rapidly into fine-grained sediments within less than $100 \mathrm{~m}$. The conglomeratic deposits (facies C1) consist of well rounded pebble to cobble conglomerate with variable amounts of sandy matrix.

In the central part of the graben, the lower Matomí Mudstone member crops out. Here, sandy fossiliferous (mainly pectinid-bearing) sandstone (facies B1) overlies the mudstone facies (A1). The sandstone is thickly bedded and some beds show abundant bioturbation. Other beds are massive or show reverse and/or normal grading. Gravelly deposits (facies D1) are interstratified $\sim 200 \mathrm{~m}$ south 
along the arroyo and are interpreted as submarine gravity flows, produced by normal faulting.

\section{Alternate stop 2-1B. Arroyo La Cantera.}

At $\mathrm{km} 69$, turn right onto the dirt road that heads west, north of the first Quaternary (?) alluvial terrace. The road leads to a small quarry in unit Tpt-c, where blocks of pink tuff are being extracted for construction and ornamental carving.

Continue $\mathrm{W}$ along the jeep trail past the quarry. Along the south wall of the arroyo, a clastsupported pebble to cobble conglomerate lies between the Tuff of Valle Curbina and the overlying welded tuffs of Mesa El Tábano. This poorly sorted conglomerate contains cobbles of rhyolite lava and welded tuff with variable amounts of sandy matrix and sparse reworked fossils. It is interpreted to be an alluvial deposit.

Upstream the arroyo turns from E-W to a N-S direction. On the west side of Arroyo La Cantera a series of rhyolite flows (Tmr), which are largely glassy, form a dome structure. The boundaries between the lavas are distinguished by local flow breccia and hydrothermal alteration. On the east side of Arroyo La Cantera, the Matomí Mudstone member crops out (Fig. 15). Here the section consists of a coarsening-upward sequence with silty mudstone at the base that grades into fossiliferous sandstone (facies B1) and into sandy conglomerate (facies $\mathrm{C} 1$ ). This section shows a regressive event prior to deposition of the Tuff of Valle Curbina. The fossil assemblage here is probably the most abundant and is described above.

\section{Stop 2.2. Southern Sierra San Fermín.}

Here we will see the distal facies of Tpvc and Tpg (lower part of the upper member of the Puertecitos Formation), and the rhyolite domes. We will hike a few tens of meters along the arroyo from base to top (W-E) to see tilted blocks with the uppermost part of the lower member of the Puertecitos Formation, and the epiclastic units Tpvc (Pth) and Ptg.

Ptg is considered the submarine equivalent of unit b of the Tuff of Mesa El Tábano (Tpt). In subaerial exposures, Tpt consists of 3 pyroclastic flow deposits which are usually thin and densely welded. The mineral assemblage (plagioclase, orthoand clino-pyroxene, and trace fayalite) suggests a relatively hot and anhydrous source magma.

A sharp decrease in thickness of the Tuff of Mesa El Tábano in preserved subaqueous sections may indicate that the flow moved above the airwater interface. Some authors maintain that pyroclastic flows interact explosively with water and generate local secondary vents (Walker, 1979). Such interaction could prevent the flow from penetrating the air-water interface as a gaseous flow, which could explain the mass-deficit in this tuff as it moved along the shore. The distal facies of the Tuff of Mesa El Tábano, however, maintained its welding texture in subaerial conditions beyond the marine embayment in the Sierra San Fermín (Lewis, 1995). The interaction between the pyroclastic flow and

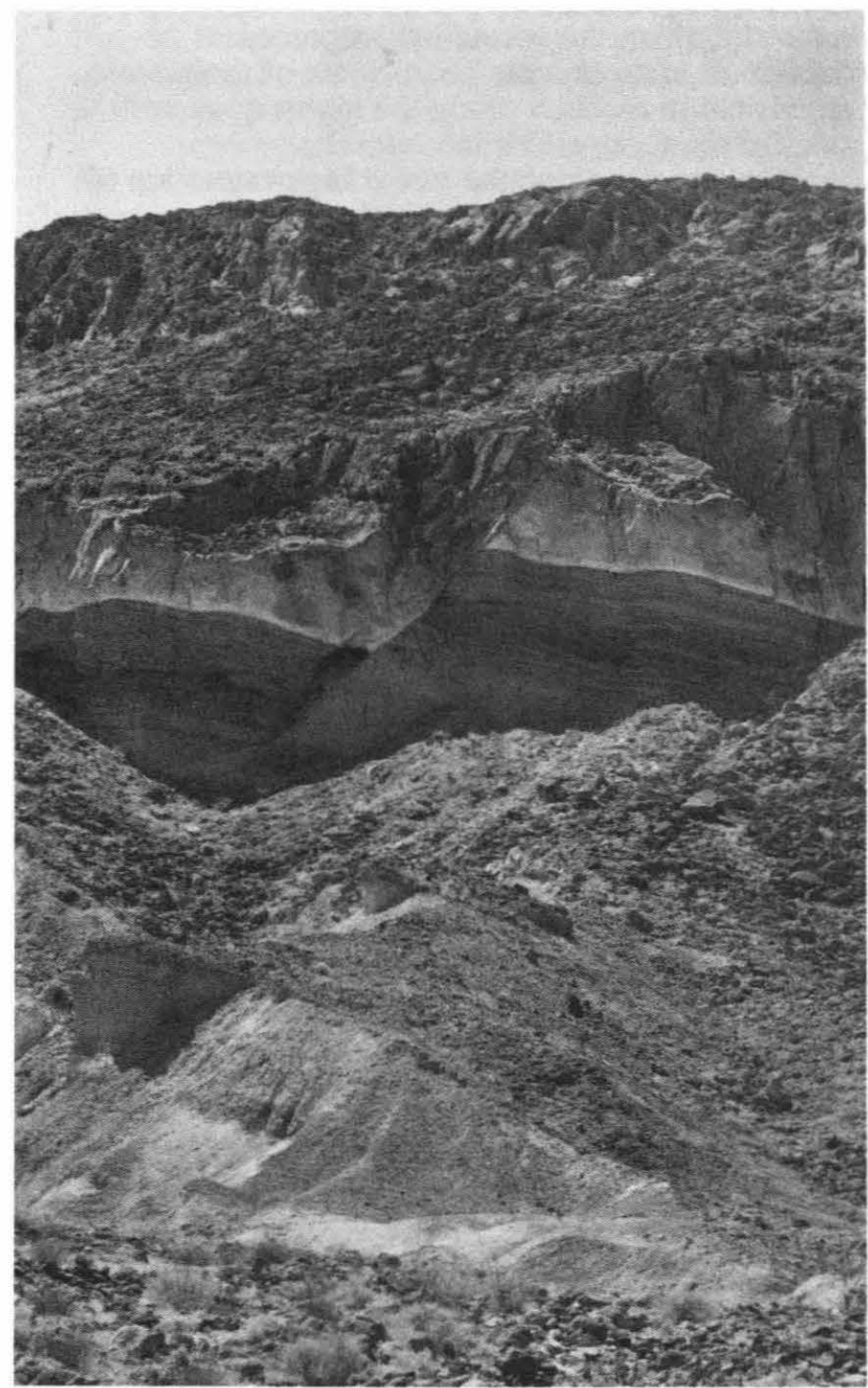

Figure 15 . View to the SW. Sandy conglomerate facies (C1) of the lower member (Matomí Mudstone Member of the Puertecitos Formation) in Arroyo La Cantera. The tuff of Valle Curbina (Tpvc) overlies the marine sequence. Note the thin whitish layer beneath Tpvc, probably a co-ignimbrite air fall deposit. Numerous NNW striking normal faults cut both the Pliocene sedimentary and volcanic units. 
sea-water may be invoked to explain the absence of the tuff of Mesa El Tábano in a submarine

environment.

The marine beds in this area are disrupted by a series of N-NE striking, E and W-dipping, high angle normal faults (site 4, Fig. 12). These faults also affect a series of rhyolite flows (Tmr) cropping out in the southern range front of the Sierra San Fermín where tilted domino blocks dip west $20^{\circ}$ to more than $30^{\circ}$. The rhyolites are more tilted than the overlying sedimentary sequence, suggesting that some slip along the normal faults preceded deposition of the marine beds. Some of these faults are visible in roadcuts along the highway on both sides of the Campo Cristina turnoff.

Continue $\mathrm{N}$ along the paved highway to $\mathrm{km} 57$ (the dirt road to Campo Cristina).

\section{Stop 2.3 Campo Cristina marine terrace.}

We will visit the type locality of the Delicias Sandstone Member of the Puertecitos Formation. The type locality of the upper section, the Campo Cristina section, is in the marine terraces east of the Sierra San Fermín, $500 \mathrm{~m}$ south of the unpaved road that runs east from $\mathrm{km} 57$ of the highway to Campo Cristina (site 4, Fig. 13). We will hike $\sim 100 \mathrm{~m}$ to see the green tuff Pte and the submarine equivalent of Ptf (Pap). From the upper part of this terrace we may see the scoria and agglutinated spatter lava flows that crop out close to the coast, the gentle folding and the domino tilted blocks of the upper marine sequence.

In this terrace the marine section is cut by a series of closely spaced, west-dipping normal faults that produce tilts up to $30^{\circ}$ to the east and cause repetition of the section. It is covered in angular unconformity with up to $14 \mathrm{~m}$ of non-marine, matrix-supported conglomerate grading up into a clast-supported conglomerate. These deposits likely represent alluvial conditions. From base to top (see Fig. 14, $\log 5$ ), the marine section includes 2.5-3.0 $\mathrm{m}$ of clast-supported and matrix-supported conglomerate with planar parallel and trough crossbedding (facies $\mathrm{C} 2$ ). Beds show sharp contact bases and normal grading (section 4, Fig. 14). This conglomerate is chiefly composed $(>85 \%)$ of clasts of volcanic rocks, with less than $10 \%$ sub-rounded plutonic (granodiorite) and metamorphic rocks (Cuevas-Jimenez, 1994). It also contains intraclasts of dark-brown sandy mudstone, derived from the underlying fine-grained deposits. The conglomerate grades into a $2-3 \mathrm{~m}$ thick white pumiceous sandstone correlated with unit Ptf from the El Canelo section (Rebolledo-Vieyra, 1994; CuevasJiménez, 1994). This volcaniclastic sandstone (Ptf in Fig. 14) is described more in detail below. It underlies, in sharp contact, a coarse sandstone interbedded with matrix-supported conglomerate, that grades up into a sequence of cyclic, fining upward, thin beds of sandy mudstone and finegrained sandstone (facies B2). This part of the sequence includes two greenish bentonitic horizons and a reworked greenish lapilli tuff toward the top (Pte in Fig. 14). Pte is the uppermost volcaniclastic deposit in the sequence.

The volcaniclastic units interbedded in the sedimentary sequence represent important stratigraphic markers. The correlation between the uppermost part of the Delicias Member is based on the presence of a pumice lapilli tuff unit labeled Ptf (Stock and others, 1991). Unit Ptf crops out towards the top of the El Canelo section, interbedded with fluvial conglomerates. On the northernmost hill in Arroyo El Canelo, it is $2.5 \mathrm{~m}$ thick and is tilted $10^{\circ}$ to the southeast. Ptf is a gray-white, poorly consolidated lapillistone, characterized by plagioclase (andesine and oligoclase), biotite, hornblende (ferro-edenite), and minor

clinopyroxene. The phenocryst assemblage suggests that this unit has no subaerial equivalent on Mesa El Tábano nor in Valle Curbina-El Canelo. Ptf from Arroyo El Canelo correlates with the volcanic sandstone that crops out at the base of the section described at stop 2-3 in the Campo Cristina terrace. There, Ptf shows planar parallel and low-angle cross bedding, and alternating coarse, mostly pumice, layers and fine ashy layers. In previous work this unit is labeled Pap (Rebolledo-Vieyra, 1994; Cuevas-Jiménez, 1994).

The facies distribution indicates that $\mathrm{Ptf}$ was deposited in subaerial and submarine conditions as an airfall deposit. In Arroyo E! Carelo it was partially reworked in a braided stream environment, but a massive basal lapilli unit, $30 \mathrm{~cm}$ thick, suggests that the primary deposit was a fallout tephra. Unit Ptf in shallow marine conditions is totally reworked. It is interbedded with coarse channel deposits in the Campo Cristina area and with fine-grained intertidal deposits east- and northward. The easternmost outcrop of Ptf is $\sim 10 \mathrm{~m}$ thick, and has in the lower 2 $\mathrm{m}$ planar parallel beds enriched in lithics and crystals. Upwards, pumiceous ash and fine-grained pumiceous lapilli with trough and tabular crossbedding and load bed structures are distinctive. No primary massive volcaniclastic facies, such as those reported for subaqueous pyroclastic flows elsewhere (e.g. Fisher and Schmincke, 1984) are present, which also is consistent with the interpretation that this is an airfall deposit.

The uppermost volcaniclastic unit (Pte) is a greenish ash, with lapilli of reddish-black scoria and yellow-beige pumice. It contains variable amounts of epiclastic phenocrysts and lithic fragments. This unit includes well-sorted beds of coarse ash and poorly-sorted beds of pumice and scoria lapilli, with 
planar parallel and cross-bedding, and normal and reverse grading. Pte is up to $2 \mathrm{~m}$ thick in Campo Cristina but less than $0.5 \mathrm{~m}$ thick in the El Coloradito area. There, it is interbedded with conglomeratic sandstone that grades into clastsupported conglomerate, which is probably a subaerial deposit. Isopachs suggest that the source of this epiclastic unit may lie to the southeast.

Retrace route to main highway and proceed north to San Felipe.

\section{ROAD LOG, DAY 3.}

Leave San Felipe at 8 a.m. Mileage is not marked on our route, so reset your odometer to 0 at the southern gas station. Then head south along the graded pipeline road (old inland highway) along the Sierra San Felipe range front. Turn right (W) at $13.8 \mathrm{~km}(8.6 \mathrm{mi})$ (end of a series of pumping stations) and head in towards the range on a jeep track.

We will enter a canyon where 4WD will be necessary. We will pass outcrops of crystalline basement rocks on both sides, and then pass the basal Tertiary unconformity at about $27.5 \mathrm{~km}$ (17.2 $\mathrm{mi})$. Above the unconformity are some thin sandstone and conglomerate units and then a massive densely welded tuff ( $\mathrm{Tmr}_{1}$ of Bryant, 1986), which here dips west. Ahead, the basin section forms prominent hogbacks. Park beyond the second (smaller) hogback and hike up to the top for a view looking NNW at the nearby stratigraphy and the rest of the basin.

\section{Stop 3-1. Overview of the Santa Rosa Basin.}

From this vantage point you can look $\mathrm{N}$ into the Tertiary sedimentary section of the Santa Rosa basin, surrounded on three sides by crystalline basement and metamorphic rocks of the Sierra San Felipe (Fig. 8). The generally W dips of the basin section are marked by prominent hogbacks of welded tuffs and lavas. We are atop one such hogback, in rhyolite tuff $\mathrm{Tmr}_{2}$. These west-dipping sedimentary and volcanic units lie in the upper plate of the Santa Rosa Basin detachment fault, which is a low-angle fault bounding the western margin of the basin exposures.

The outcrops near us are separated from the main part of the basin section by a later, high-angle fault, which strikes about $\mathrm{N} 70^{\circ} \mathrm{E}$ and has apparent sinistral displacement in map view. Thus the entire basin section is exposed in cross-section ahead of us. Immediately to the east, you can see lower units of the basin section, including the massive, densely welded tuff $\mathrm{Tmr}_{1}$.
Return to the vehicles and walk a short distance up the arroyo to view exposures of sedimentary rocks and tuffs on the $\mathrm{E}$ side of the drainage.

\section{Stop 3-2. Volcanic and fluvial strata of units $\operatorname{Tmf}_{1^{-}}$ Tmf $_{3}$.}

Here we will examine details of the volcanic and sedimentary rocks, including mudstones of $\mathrm{Tmf}_{1}$, bedded sandstones and conglomerate lenses of $\mathrm{Tmf}_{2}$ and $\mathrm{Tmf}_{3}$, and the welded tuff $\mathrm{Tmr}_{2}$. See Fig. 16 for diagrams indicating the possible correlations between these volcanic rocks and those of adjacent areas.

Continue up the arroyo along the jeep trail. As the trail bears right into a narrower canyon, we are crossing the major ENE-striking fault that offsets the southern part of the basin sinistrally from the rest of the basin exposures (Fig. 8). We will be driving obliquely upsection, nearly parallel to section, through the entire sequence of basin units again.

At $33.1 \mathrm{~km}(20.7 \mathrm{mi})$, exit right from the main jeep trail and head up a side canyon. Park at $36 \mathrm{~km}$ $(22.5 \mathrm{mi})$ near cliffs of steeply dipping granitic breccias and sandstones. Walk about 5 minutes further up canyon, to reach exposures of the lowangle normal fault on the right side of the canyon. Note the dip of the upper plate sedimentary deposits into the fault, and note also that these sedimentary rocks are coarsening into breccias of basement clasts as you approach the fault.

\section{Stop 3-3. Santa Rosa Basin detachment fault.}

This exposure demonstrates the major characteristics of the Santa Rosa Basin detachment fault. It is quite planar, NE-striking, low-dipping (about $22^{\circ}$ ), and characterized by a $\sim 20 \mathrm{~cm}$ wide clay gouge zone with numerous anastomosing shear surfaces. The nature of the breccias and alluvial fan deposits near the fault can also be clearly seen. (See discussion of the Santa Rosa Basin, above.)

Retrace tracks out of the Santa Rosa basin and return to San Felipe.

\section{ACKNOWLEDGMENTS}

Martín-Barajas was partially supported by CONACYT grants 1224-T9203 and 3250-T. Stock was supported by NSF grant EAR-9296102. Contribution Number 5663 of the Division of Geological and Planetary Sciences, California Institute of Technology. 
Figure 16. Stratigraphic correlations of volcanic sequences in the region of the field trip, after Lewis (1994). Other sources of data: Bryant (1986), Stock and others (1991), Stock (1989, 1993), Martín-Barajas and others (1993, 1995). Letters A-F correspond to locations of sections shown in Fig. 5.
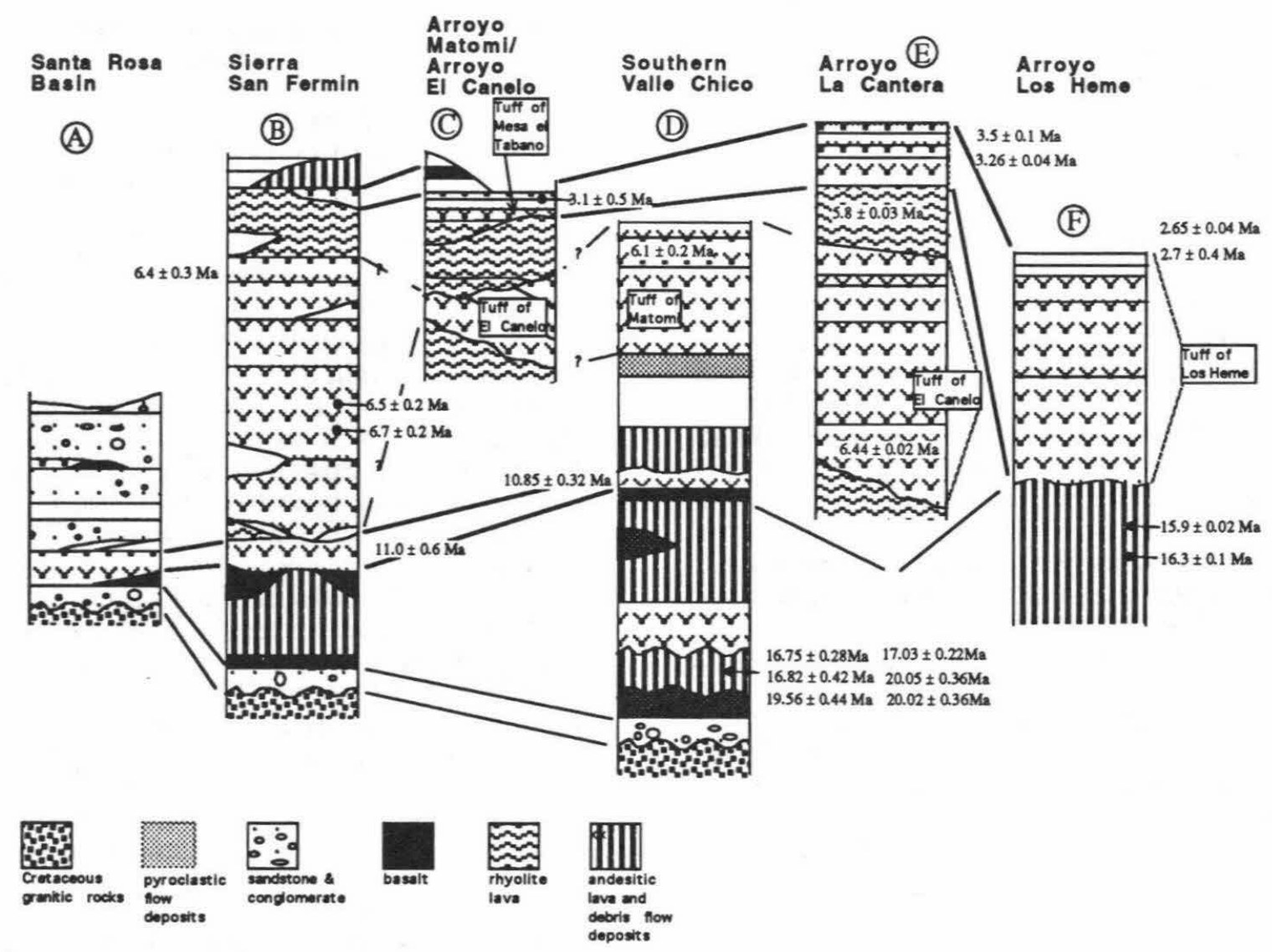

\section{REFERENCES CITED}

Alvarez-Rosales, J. and González-López, M., 1995, Resultados de los pozos exploratorios en Laguna Salada, B.C.: III International Meeting on the Geology of the Baja California Peninsula, Abstract, La Paz, BCS, México, p. 4-5.

Andersen, R. L., 1973, Geology of the Playa San Felipe quadrangle, Baja California, Mexico [M.S. thesis]: San Diego, California, San Diego State University, 214 p.

Axen, G. J., 1995, Extensional segmentation of the Main Gulf Escarpment, Mexico and the United States: Geology, v. 23, p. 515-518.

Barnard, F. L., 1968, Structure and Tectonics of the Sierra Cucapás, Northeastern Baja California and Imperial County, California [Ph.D. thesis]: Boulder, Colorado, University of Colorado, 155 p.

Bell-Countryman, P., 1984, Environments of deposition of the Pliocene Imperial Formation, Coyote Mountains, southwest Salton Trough, in Rigsby, C.A., ed., The Imperial Basin: Tectonics,
Sedimentation, and Thermal Aspects: Pacific Section SEPM Book 40, p. 45-70.

Boehm, M. C. F., 1982, Biostratigraphy, lithostratigraphy, and paleoenvironments of the Miocene-Pliocene San Felipe Marine Sequence, Baja California Norte, Mexico [M.S. thesis]: Stanford, California, Stanford University, 325 p. Boehm, M. C. F., 1984, An overview of the lithostratigraphy, biostratigraphy, and paleoenvironments of the late Neogene San Felipe marine sequence, Baja California, Mexico, in Frizzell, V.A., ed., Geology of the Baja California Peninsula: Pacific Section SEPM Book 39, p. 253-266.

Bryant, B. A., 1986, Geology of the Sierra Santa Rosa basin, Baja California, Mexico [M.S. thesis]: San Diego, California, San Diego State University, $75 \mathrm{pp}$.

Calvert, S. E., 1964, Factors affecting distribution of laminated diatomaceous sediments in Gulf of California, in Van Andel, Tj. H., and Shor, G. G., Jr., eds., Marine Geology of the Gulf of 
California: American Association of Petroleum Geologists Memoir 3, p. 311-330.

Chávez, R. E., 1990, Gravity interpretation of the Laguna Salada Basin, Baja California, Mexico: Geofísica Internacional, v. 29, 129-135.

Cotton, M. L., and Vonder Haar, S., 1981, Microfossils from Cerro Prieto Wells, Baja California, Mexico: Segundo Simposio sobre el Campo Geotérmico de Cerro Prieto, Comisión Federal de Electricidad-USA, Department of Energy, Mexicali, B. C., Oct. 1979, p. 162-168. Cuevas-Jiménez, A., 1994, Estratigrafía de las terrazas marinas al este de la Sierra San Fermín, NE de Baja California, Mexico [Undergraduate Research Report]: Ensenada, Mexico, Facultad de Ciencias Marinas, Universidad Autónoma de Baja California, México, 80 pp.

Dibblee, T. W., Jr., 1984, Stratigraphy and tectonics of the San Felipe Hills, Borrego Badlands, Superstition Hills, and vicinity, in SEPM book 40 , p. $31-34$.

Dokka, R. K., and Merriam, R. H., 1982, Late Cenozoic extension of northeastern Baja California, Mexico: Geological Society of America Bulletin, v. 93, p. 371-378.

Dorsey, R. J., Stone, K. A., and Umhoefer, P. J., 1996, Stratigraphy, sedimentology and tectonic development of the southeastern Pliocene Loreto Basin, Baja California Sur, Mexico, in Johnson, M., and Ledesma-Vázquez, J., eds., Pliocene carbonates and related facies flanking the Gulf of California, Baja California Sur, Mexico: Geological Society of America Special Paper (in press).

Douglas, R. G., 1981, Paleoecology of continental margin basins: A modern case history from the borderland of Southern California, in Douglas, R. G., Colburn, I. P., Gorsline, D. E., eds., Depositional systems of of active continental margins basins: Soc. Econ. Paleontol. Mineral., Short course notes, p. 121-156.

Elders, W. A., Rex, R., Meidev, T., Robinson, P. T., and Biehler, S., 1972, Crustal spreading in southern California: Science, v. 178, p. 15-24.

Fenby, S. S., and Gastil, R. G., 1991, A seismotectonic map of the Gulf of California and surrounding areas, in Dauphin, J. P. and Simoneit, B. R., eds., The Gulf and Peninsular Provinces of the Californias: American Association of Petroleum Geologists Memoir 47, pp. 79-83.

Fisher, R. V., and Schmincke, H.-U., 1984, Pyroclastic Rocks: Berlin, Springer-Verlag, 472 p.

García-Abdeselem, J., Martín-Barajas, A., EspinosaCardeña, J. M., and Suárez-Vidal, F., 1996, Residual isostatic gravity and crustal structure at
Laguna Salada, Baja California, Mexico: submitted to Tectonics, January 1996.

Gastil, R. G., Lemone, D. V., and Stewart, W. J., 1973, Permian fusilinids from near San Felipe, Baja California, American Association of Petroleum Geologists Bulletin, v. 57, p. 746747.

Gastil, R. G., Phillips, R. P., and Allison, E. C., 1975, Reconnaissance geology of the State of Baja California: Geological Society of America Memoir 140, 170 p.

Gastil, R. G., Krummenacher, D., and Minch, J., 1979, The record of Cenozoic volcanism around the Gulf of California: Geological Society of America Bulletin, v. 90, p. 839-857.

Heckel, P. H., 1972, Recognition of ancient shallow marine environments: in Rigby, J. K., and Hamblin, W. K. , eds., Recognition of ancient sedimentary environments: Soc. Econ. Paleontol. Mineral., Special Pub. 16, p. 226286.

Hertlein, L. G., 1968, Three late Cenozoic molluscan faunules from Baja California with a note on diatomite from west of San Felipe: Proceedings of the California Academy of Sciences, 4th Ser., v. 30 , no. 19, 401-405.

Ingle, J. C., Jr., 1981, Origin of Neogene diatomites around the northern Pacific rim, in Garrison, R. E., and others, eds., The Monterey Formation and related siliceous rocks of California: Proc. Research Symposium, Pacific Section SEPM, 1981 Ann. Amer. Ass. Pet. Geol. Mtg., San Francisco, CA, p. 159-180.

Isaac, S.,1987, Geology and structure of the Yuha desert between Ocotillo, California, U.S.A. and Laguna Salada, Baja California, Mexico [M.S. thesis]: San Diego, California, San Diego State University, $165 \mathrm{p}$.

Johnson, N. M., Officer, C. B., Opdyke, N. D., Woodard, G. D., Zeitler, P. K. and Lindsay, E. H., 1983, Rates of late Cenozoic tectonism in the Vallecito-Fish Creek basin, western Imperial Valley, California: Geology, v. 11, p. 664-667.

Keen, A. M. and Coan, E., 1974, Marine mollusca genera of westhern North America, 2nd. edition: Stanford, California, Stanford University Press, $161 \mathrm{p}$.

Kelm, L. D., 1971, A gravity and magnetic study of the Laguna Salada, B.C. [M.S. thesis]: San Diego, California, San Diego State University, $103 \mathrm{p}$.

Lee, J., Miller, M. M., Crippen, R., Hacker, B., and Ledesma-Vazquez, J., 1996, Middle Miocene extension in the Gulf Extensional Province, Baja California: Evidence from the southern Sierra Juarez: Geological Society of America Bulletin (in press). 
Leier-Engelhardt, P., 1993, Middle Paleozoic strata of the Sierra Las Pintas, northeastern Baja California Norte, Mexico, in: Gastil, R. G., and Miller, R., eds., Prebatholithic stratigraphy of Peninsular California: Geological Society of America Special Paper, v. 279, p. 23-42.

Lewis, C. J., 1994, Constraints on extension in the Gulf Extensional Province from the Sierra San Fermín, northeastern Baja California, Mexico [Ph.D. thesis]: Cambridge, Massachusetts, Harvard University, $361 \mathrm{p}$.

Lewis, C. J., 1996, Stratigraphy and geochronology of Miocene and Pliocene volcanic and marine rocks in the Sierra San Fermín and southern Sierra San Felipe, Baja California, Mexico: Geofisica Internacional v. 35, no. 1, p. 3-25.

Lewis, C. J., and Stock, J. M., 1996, Paleomagnetic evidence of localized rotations during Neogene extension in the Sierra San Fermín, northeastern Baja California, Mexico, submitted to Journal of Geophysical Research, Oct. 1994; in revision, March 1996.

Lomnitz, C., Mooser, F., Allen, C. R., Brune, J. N., and Thatcher, W., 1970, Sismicidad y tectónica de la región norte del Golfo de California, México, Resultados preliminares: Geofísica Internacional, v. 10, p. 37-48.

Lucchitta, I, 1972, Early history of the Colorado River in the Basin and Range province: Geological Society of America Bulletin, v. 83, p. 1933-1948.

Lyons, J. D., and Van de Kamp, C. P., 1979, Subsurface geological and geophysical study of the Cerro Prieto Geothermal Field, in Second symposium on the Cerro Prieto Geothermal Field, Comision Federal de Electricidad-U.S. Dept. of Energy, Div. of Geothermal Energy, p . 173-186.

Martín-Barajas, A. and Stock, J. M., 1993, Estratigrafía volcánica y características petrológicas de la secuencia volcánica de Puertecitos, NE de Baja California. Transición del vulcanismo de arco a vulcanismo de rift en el golfo, in Delgado-Argote, L. and MartínBarajas, A., eds., Contribuciones a la tectónica del occidente de México: Monografías de la Unión Geofísica Mexicana, No. 1, p. 66-89. Martín-Barajas, A., Téllez-Duarte, M., and RendónMárquez, G., 1993, Estratigrafía y ambientes de depósito de la secuencia marina de Puertecitos, NE de Baja California. Implicaciones sobre la evolución de la margen occidental de la depresion del golfo. in Delgado-Argote, L. and Martín-Barajas, A., eds., Contribuciones a la tectónica del occidente de México: Monografías de la Unión Geofísica Mexicana, No. 1, p. 90114.
Martín-Barajas, A., Stock, J. M., Layer, P., Renne, P., Hausback, B., and López-Martínez, M., 1995, Arc-rift transition volcanism in the Puertecitos Volcanic Province, northeastern Baja California, Mexico: Geological Society of America Bulletin, v. 107, p. 407-424.

Martín-Barajas, A., Téllez-Duarte, M., and Stock, J.M., 1996, The Puertecitos Formation: Pliocene volcaniclastic sedimentation along an accommodation zone in northeastern Baja California. in Johnson, M.E., and LedesmaVázquez, J., eds., Pliocene Carbonate and Related Facies Flanking the Gulf of California, Baja California, Mexico: Geological Society of America Special Paper (in press).

Merriam, R., and Bandy, O. L., 1965, Source of the upper Cenozoic sediments in the Colorado delta region: Journal of Sedimentary Petrology., v. 35 , p. $911-916$.

Morris, R. H., Abbott, D. P., and Haderlie, E. C., 1980, Intertidal invertebrates of California: Stanford, California, Stanford University Press, 169 p.

Mueller, K., and Rockwell, T. K., 1991, Late Quaternary structural evolution of the western margin of the Sierra Cucapá, northern Baja California, in Dauphin, J. P. and Simoneit, B. J., eds., The Gulf and Peninsular Province of the Californias: American Association of Petroleum Geologists Memoir 47, p. 249-260.

Puente, C . I., and de la Peña, L. A., Geología del Campo Geotérmico de Cerro Prieto, in Proceedings, First symposium on the Cerro Prieto Geothermal Field, Baja California, Mexico, September, 1978: Lawrence Berkeley Laboratory LBL-7098, p. 17-40, 1979.

Quinn, A. H., and Cronin, M. T., 1984, Micropaleontology and depositional environments of the Imperial and Palm Spring formations, Imperial Valley, California, in Rigsby, C. A., ed., The Imperial Basin: Tectonics, Sedimentation, and Thermal aspects: Pacific Section SEPM Book 40, p. 71-85.

Rebolledo-Vieyra, M., 1994, Implicaciones tectónicas de la deformación en el PlioCuaternario de las terrazas marinas al norte de Puertecitos, NE de Baja California [M.S. thesis]: Ensenada, B.C., Mexico, Centro de Investigación Científica y Educación Superior de Ensenada, 119 p.

Rendon-Marquez, G., 1992, Estratigrafía de los depósitos del Neógeno en la región de Puertecitos, NE de Baja California

[Undergraduate research report]: Ensenada, B.C., México, Facultad de Ciencias Marinas, Universidad Autonoma de Baja California, 59 p. Romero-Espejel, H., 1996, Geología estructural en el escarpe oriental de la Síerra Juárez, Baja 
California, México [M.S. thesis in progress]:

Ensenada, B.C., Mexico, División de Ciencias de la Tierra, Centro de Investigación Científica y Educación Superior de Ensenada.

Siem, M. E., 1992, The structure and petrology of Sierra El Mayor, northeastern Baja California, Mexico [M.S. thesis]: San Diego, California, San Diego State University, 243 p.

Siem, M., and Gastil, R. G., 1994, Mid-Tertiary to Holocene extension associated with the development of the Sierra El Mayor metamorphic core complex, northeastern Baja California, Mexico, in Geological Investigations of an Active Margin, 1994 GSA Cordilleran Section Guidebook: San Bernardino County Museum Association, p. 107-119.

Smith, J. T., Smith, J. G., Ingle, J. G., Gastil, R. G., Boehm, M. C., Roldán, J. Q., and Casey, R. E., 1985, Fossil and K-Ar age constraints on upper middle Miocene conglomerate, SW Isla Tiburón, Gulf of California: Geological Society of America Abstracts with Programs, 17, p. 409.

Smith, J. T., 1991, Cenozoic marine mollusks and paleogeography of the Gulf of California, in Dauphin, J.P. and Simoneit, B., eds., The Gulf and Peninsular provinces of the Californias: American Association of Petroleum Geologists Memoir 47, p. 637-666.

Stock, J. M., 1993, The geology of southern Valle Chico and adjacent regions, Baja California, Mexico: Geological Society of America Map and Chart Series MCH-076, 2 sheets, scale $1: 25,000,4$ p. text.

Stock, J. M. and Hodges, K. V., 1990, Miocene to Recent structural development of an extensional accommodation zone, NE Baja California, Mexico: Journal of Structural Geology, v.12, 3, p. 315-328.

Stock, J. M., Martín-Barajas, A., Suárez-Vidal., F. and Miller, M., 1991, Miocene to Holocene extensional tectonics and volcanic stratigraphy of NE Baja California, Mexico. in: Walawender, M. and Hanan, B., eds., Geological excursions in southern California and Mexico: Geological Society of America, San Diego, California, p. 44-67.

Theyer, F., Mato, C. Y., and Hammond, S. R., 1978, Paleomagnetic and geochronologic calibration of latest Oligocene to Pliocene radiolarian events, equatorial Pacific: Marine Micropaleontology, v. 3, p. 377-395.

Umhoefer, P. J., Dorsey, R. J., and Renne, P., 1994, Tectonics of the Pliocene Loreto basin, Baja California Sur, Mexico, and the evolution of the Gulf of California: Geology, v. 22, p. 649-652.

Vázquez-Hernández, S., 1996, Estratigrafía y ambientes de depósito de la porción noroeste de la Sierra El Mayor, cuenca de Laguna Salada,
Baja California [M.S. thesis in progress]: Ensenada, B.C., Mexico, División de Ciencias de la Tierra, CICESE.

Valdez, K., 1977, Stratigraphy of the Cenozoic volcanic and sedimentary rocks of Sierra Santa Rosa, Baja California, Mexico [unpublished senior report]: San Diego, California, San Diego State University.

Walker, G. P. L., 1979, A volcanic ash generated by explosions where ignimbrite entered the sea: Nature, v. 281, p. 642-646. 